\title{
Laboreal
}

Volume $17 \mathrm{~N}^{\circ} 1$ | 2021

Trabalhar hoje: mudanças, permanências, estratégias, reinvenções

\section{Do preconceito à expertise: percepção de suspeitos em abordagens policiais}

Del prejuicio a la experiencia: percepción de fallas en los enfoques policiales

Du préjudice à l'expertise: perception des suspects dans les approches policières

From prejudice to expertise: perception of suspects in police approaches

\section{Guilherme Fernando Soares de Araújo}

\section{(2) OpenEdition}

\section{Journals}

Edição electrónica

URL: https://journals.openedition.org/laboreal/17710

DOI: $10.4000 /$ laboreal. 17710

ISSN: 1646-5237

Editora

Universidade do Porto

Refêrencia eletrónica

Guilherme Fernando Soares de Araújo, «Do preconceito à expertise: percepção de suspeitos em abordagens policiais», Laboreal [Online], Volume 17 Nº1 | 2021, posto online no dia 18 junho 2021 , consultado o 20 junho 2021. URL: http://journals.openedition.org/laboreal/17710 ; DOI: https:// doi.org/10.4000/laboreal.17710

Este documento foi criado de forma automática no dia 20 junho 2021.

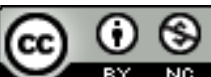

Laboreal está licenciado com uma Licença Creative Commons - Atribuição-NãoComercial 4.0 Internacional. 


\section{Do preconceito à expertise: percepção de suspeitos em abordagens policiais}

Del prejuicio a la experiencia: percepción de fallas en los enfoques policiales

Du préjudice à l'expertise: perception des suspects dans les approches policières

From prejudice to expertise: perception of suspects in police approaches

\section{Guilherme Fernando Soares de Araújo}

\section{NOTA DO EDITOR}

Manuscrito recebido em: 19/08/2020

Aceite após peritagem em: 26/02/2021

\section{Introdução}

1 Os serviços públicos de proteção social executados por policiais, bombeiros e paramédicos são vitais para o bom funcionamento comunitário, e quando bem empregados, podem gerar bem-estar e qualidade de vida a toda a sociedade. No entanto, é comum que ações policiais sejam lembradas pela violência, pelo uso desmedido de força ou pela arbitrariedade. Muitos julgamentos e decisões dos agentes são executados em condições inéditas, incertas e ambíguas, de forma intuitiva, espontâneas e fluídas, no decorrer da ação. Certamente, abusos podem acontecer; resta saber, como avaliá-los e discriminá-los da força necessária.

2 Nas ocorrências diárias, os agentes devem fazer o uso da força com equilíbrio, apenas o necessário para quebrar a resistência dos abordados ou infratores da lei. Contudo, o labor diário acontece sob condições organizacionais e sociais diversas (operações em locais perigosos, deficiência de equipamentos ou materiais, ocorrências de alto risco, 
afastamento familiar), predominantemente de caráter negativo, podendo contribuir para a aplicação excessiva ou deficitária da força na manutenção da ordem. Assim, o trabalho dos policiais militares é um dos ofícios mais estressantes descritos pela literatura, dado que trabalham constantemente com conflitos sociais e, por necessidade de ofício, recorrem a técnicas de coerção física, coerção psicológica e controle social (Portela \& Bughay Filho, 2007).

3 As interações conflituosas entre o policial, o cidadão - que pode se tornar abordado - e o criminoso desenvolvem-se nessas condições de conflito social aberto ou potencial. Geralmente, os agentes são treinados para atuar em situações potencialmente violentas, mas com foco mais na capacidade de demonstrar bom domínio tático (em que se enfatizam, por exemplo, as habilidades de posicionamento, velocidade, segurança, técnica e força) e menos na capacidade de julgar e tomar decisões em situação, face aos dilemas encontrados (como disparar ou não disparar, abordar ou não abordar) (Suss \& Ward, 2013).

4 Isso pode contribuir para os maus resultados nas intervenções policiais, uma vez que grande número de policiais e cidadãos são mortos em diversas operações. Os dados de 2013, 2014 e 2015 são apresentados a seguir, nas Tabelas 1 e 2.

Tabela 1 : Mortes decorrentes de intervenção policial

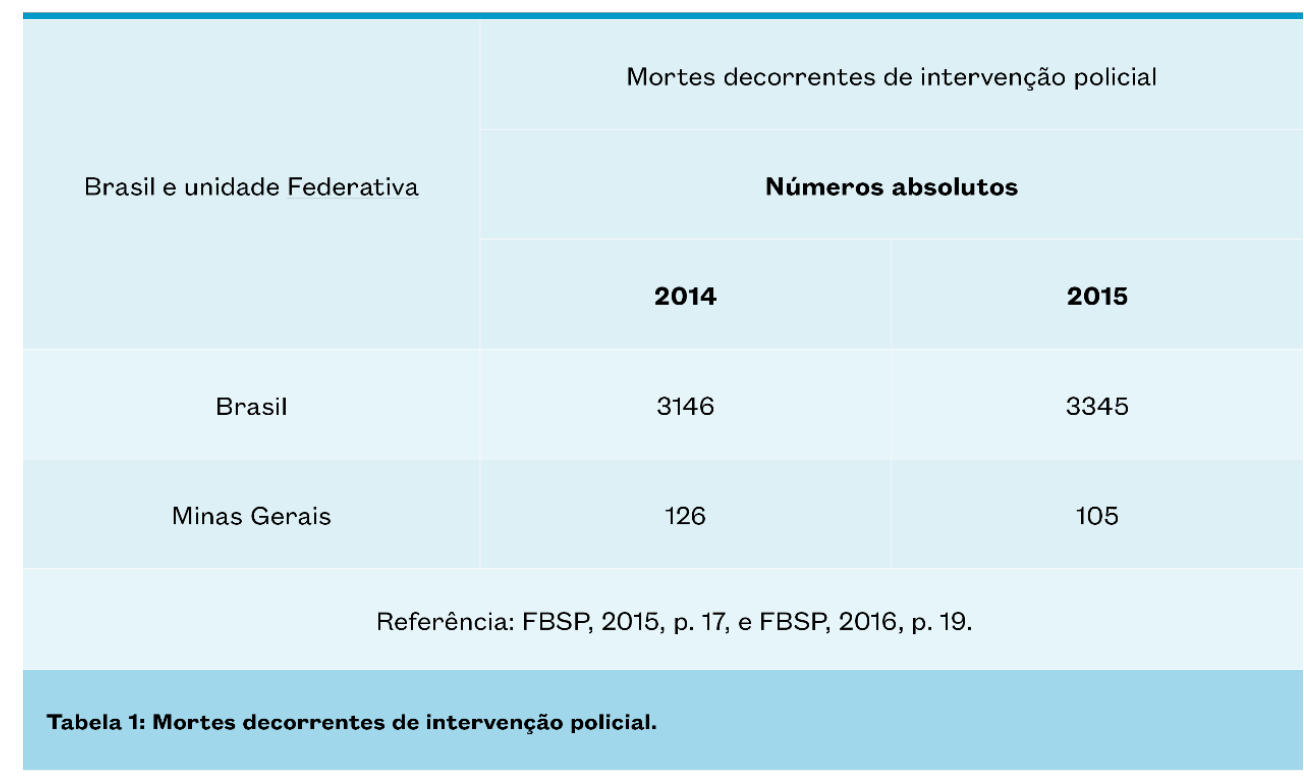

Tabela 1: Mortes decorrentes de intervenção policial 
Tabela 2 : Policiais miliatres mortos em serviço ou fora de serviço

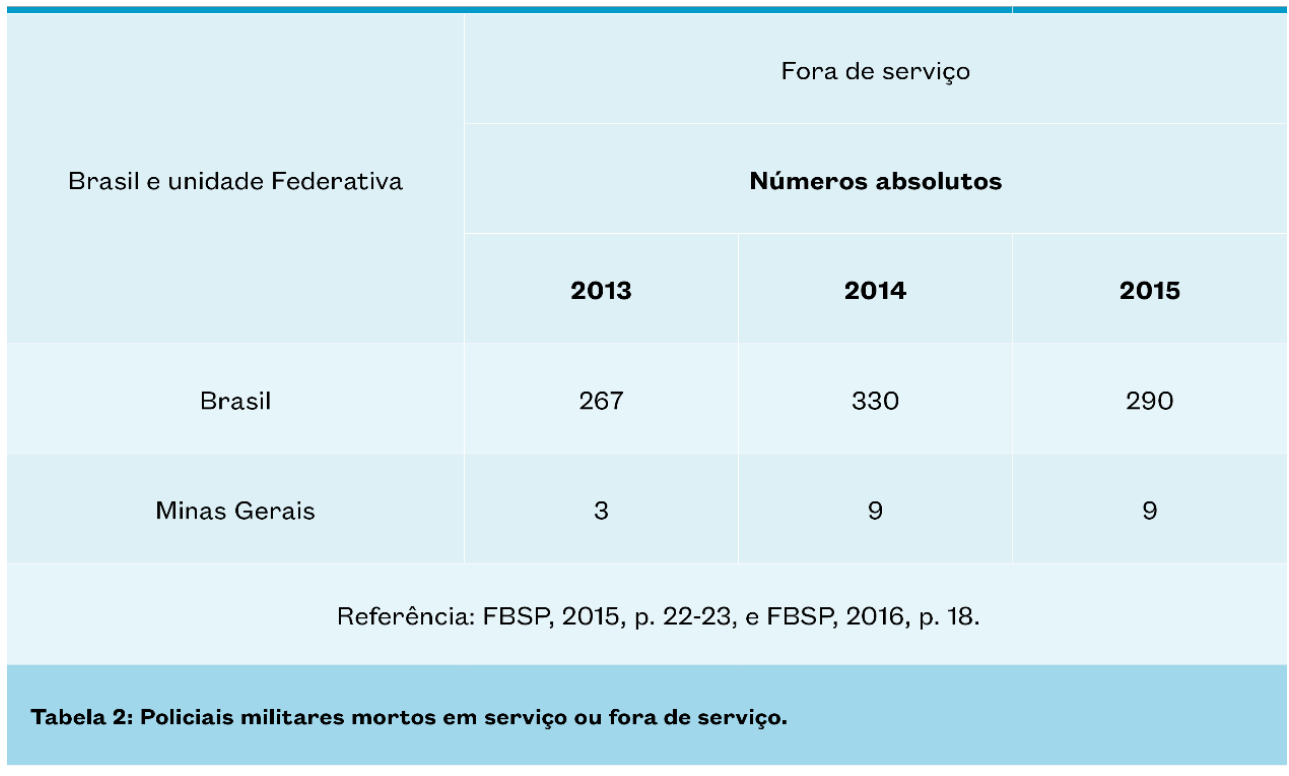

Tabela 2 : Policiais miliatres mortos em serviço ou fora de serviço

A população reconhece as dificuldades enfrentadas pela polícia brasileira, dado que $64 \%$ daquela acredita que os policiais são caçados pelo crime, $63 \%$ acha que os policiais não têm boas condições de trabalho, e 50\% afirma que a PM é eficiente em garantir a segurança da população. Contudo, $59 \%$ da população relata ter medo de ser vítima de violência policial, e 70\% acredita que as polícias - militar e civil - exagera na aplicação do uso da força de seu poder de polícia (FBSP, 2016, p. 6).

o poder de polícia ou poder discricionário de polícia é inerente às atividades de abordagem. Ele pode ser entendido como um conjunto de normas táticas capazes de limitar ou ampliar a tomada de decisão e julgamento e sancionar ou autorizar a intervenção do Estado na verificação de cada indivíduo, executada pelos seus agentes policiais militares quando está em jogo o interesse social. Tal poder é necessário para um bom funcionamento social, organizacional e coletivo (Reis, 2016). o art. 78. do Código Tributário Nacional considera poder de polícia:

\footnotetext{
"A atividade da administração pública que, limitando ou disciplinando direito, interesse ou liberdade, regula a prática de ato ou abstenção de fato, em razão de interesse público concernente à segurança, à higiene, à ordem, aos costumes, à disciplina da produção e do mercado, ao exercício de atividades econômicas dependentes de concessão ou autorização do Poder Público, à tranquilidade pública ou ao respeito à propriedade e aos direitos individuais ou coletivos" (Brasil, 2010)
}

o papel da polícia ao longo da história foi o de fazer o uso da força para a manutenção da ordem social e do bem comum. $\mathrm{O}$ uso da energia policial é legitimado quando se pretende assegurar a ordem pública ou proteger a segurança de terceiros, reprimindo ações delituosas individuais (Reis, 2016). Os policiais militares, enquanto instituição, construíram um "sentido de missão", de "serviço para o bem coletivo" e de "suspeição em relação aos cidadãos", os quais constituem três aspectos da cultura policial (Reis, 2016, p. 86). 
O sentido de missão está relacionado ao “(...) sentimento de que o policiamento não é apenas um trabalho, mas um meio de vida com um propósito útil, pelo menos a princípio" (Reiner, 2004, p. 136). O sentido de serviço para o bem coletivo pode ser traduzido como um sentir-se como alguém que exerce “(...) um papel essencial na salvaguarda da ordem social. $\mathrm{O}$ mito da indispensabilidade da polícia, de sua missão essencial de 'proteger e servir"' (Reiner, 2004, p. 137). 0 aspecto da suspeição constitui, por sua vez, um “(...) produto da necessidade de manter certa atenção para a sinalização de problemas, de perigo potencial e de pistas de crimes. É uma resposta ao perigo (...) e também um efeito do sentido de missão" (Reiner, 2004, p. 139-140).

Segundo Reiner (2004), analisar e compreender como se constrói a visão policial acerca do mundo social e de sua razão de ser nesse mundo auxiliam no conhecimento sobre suas construções sociais, que atribuem valores e sentidos ao que há no mundo. Mas, de acordo com o mesmo autor, "a cultura da polícia não significa simplesmente atitudes de polícia” (2004, p. 131). Para entender tal cultura, é necessário extrapolar e aprofundar a análise ao nível da atividade real, ao nível da prática.

o Polícia Militar é o agente responsável pelo chamado policiamento preventivo ostensivo. Isso significa que ele serve para prevenir/controlar as ilegalidades de maneira imediata. Enquanto o policial Civil é um agente mais voltado para a investigação criminal e responsabilidades (CEPM, 2021).

11 Esta pesquisa foi motivada pela preocupação de entender o processo de tomada de decisão, percepção e julgamento de policiais militares em ação, antes da abordagem. As decisões e julgamentos não mostraram ser produto de uma cognição consciente, como descrito pela escola clássica cognitivista, que recorre a modelos lógico-formais para investigar os estados de consciência. Em vez disso, como mencionado, trata-se de julgamentos e decisões intuitivos, gerados em contexto e na ação, de forma espontânea (Sadler-Smith \& Akinci, 2014).

12 Assim, ao buscar entender com mais detalhes o processo de tomada de decisão no contexto de atuação policial - no qual o uso da força é um recurso previsto e, na medida certa, legítimo -, esta pesquisa não se propõe apenas a aplicar análises teóricas, mas pode se mostrar oportuna também para melhorar a segurança pública. Embora tenha havido significativos avanços teóricos no estudo das tomadas de decisão e julgamento em situações controladas, há poucas pesquisas empíricas da atividade policial real. Este trabalho visa estudar tais atividades e preencher uma parte dessa lacuna.

\subsection{Abordagem policial: um verdadeiro dilema}

Diversas reclamações e queixas da população quanto as abordagens policiais no Brasil e no mundo são frequentemente manchetes de jornais e estimulam o debate sobre a necessidade de se compreender tais ações. No Brasil, persistem os maus-tratos e outras práticas abusivas cometidas por agentes da lei. O governo tem feito esforços para conter a violência praticada por policiais, mas os resultados dessas ações ainda são inexpressivos (FBSP, 2016). Segundo o relatório divulgado anualmente pela organização Human Rights Watch, um dos principais desafios do Brasil permanece sendo a violência policial desmedida (HRW, 2016).

No entanto, essa situação não é exclusividade do nosso país. Nos Estados Unidos, por exemplo, os casos de violência policial que mais repercutem são aqueles de que são vítimas jovens negros. Em 2014, a morte de Eric Garner, estrangulado por um policial, 
em Nova Iorque, provocou indignação em toda a nação estadunidense. Um mês mais tarde, no Missouri, o adolescente Michael Brown foi alvejado por agentes em um tiroteio, desencadeando diversas manifestações, em especial após a absolvição dos policiais envolvidos no caso. Em novembro do mesmo ano, Tamir Rice, que tinha apenas 12 anos de idade, foi morto por policiais em Ohio, quando brincava com sua pistola de brinquedo. Em 2015, na Carolina do Sul, Walter L. Scott foi morto por um policial após uma blitz. No mesmo ano, Freddie Gray foi morto enquanto era conduzido à delegacia.

o policial envolvido no caso de Walter L. Scott foi acusado de homicídio, com base em um vídeo amador. Em Baltimore, o motorista da viatura policial em que Freddie Gray foi morto foi acusado de assassinato em segundo grau. Em todos os casos anteriores, não houve acusações formais do Estado contra seus agentes.

No Brasil, o caso Amarildo (Rio de janeiro, julho de 2013) tornou-se símbolo de abuso de autoridade e de violência policial. $\mathrm{O}$ ajudante de pedreiro foi retirado de sua casa, na favela da Rocinha, em direção à UPP. Ele não foi mais encontrado, sendo dado como morto pelas autoridades judiciárias.

17 Segundo Pinheiro (1997), a violência policial no Brasil e no mundo tem base num passado histórico-cultural fundamentalmente marcado por raízes autoritárias socialmente implantadas:
“(...) as práticas autoritárias seriam ainda resultado direto da continuidade e de uma longa tradição de autoritarismo das elites contra as não elites que, por sua vez, são reproduzidas entre os mais pobres. Essas práticas autoritárias e violentas são empregadas também pelos órgãos encarregados de fazer a segurança e promover a justiça em nosso país (...)" (Pinheiro, 1997, p. 47)

18 A figura do suspeito contracena com as dos policiais, desde que o Brasil império constituiu órgãos de controle social. Contudo, percebe-se que as características dos abordados se altera à medida que diferem as características do cenário social. No final do século XVIII e início do século XIX, os suspeitos eram os capoeiras. As operações policiais eram pautadas para a repressão e a captura de indivíduos que se enquadravam nessa categoria. Nessa época, a dança capoeira era praticada, principalmente, por negros, escravos e libertos, geralmente com uso de instrumentos de percussão (Holloway \& Castro Azevedo, 1997). Assim, qualquer cidadão que se enquadrasse nessas características poderia ser abordado.

19 A capoeira foi um paradigma cultural que estigmatizou determinado grupo social (negros) em determinado período histórico. Assim, como os cidadãos que não possuíssem vínculo empregatício, comprovados em carteira de trabalho, eram enquadrados na categoria "vadio". Percebe-se, o destaque que o estado Brasileiro, possuía e possui, como agente ativo no processo de construção dos paradigmas histórico-culturais de suspeição e ilegalidade, gerando controles sociais, preconceituosos.

20 Essas práticas - repressão de vadios e capoeiras - refletiam a manutenção da ordem e a política de repressão do estado, especialmente das instituições policiais. A maioria das prisões efetuadas pela polícia eram pautadas na ordem pública e na política econômica vigente (escravocrata). Segundo Holloway e Castro Azevedo (1997), a constituição da ordem pública era preocupação frequente das instituições policiais e dos policiais, que 
no cumprimento da lei faziam julgamentos prematuros baseados nas características que a lei impunha. Gerando violência, preconceito legalizado e controle social.

21 Considerando-se esses aspectos, pode-se pensar que a abordagem legal está ligada à preconceito estrutural de um país, produzido pela organização econômica e política da sociedade, na qual se manifestam as desigualdades sócio-raciais. A forma de as instituições militares, que participam da manutenção da ordem social e do bem comum, tratarem as populações mais carentes dependerá dos controles institucionais externos e internos ao aparelho policial (Guimarães et al., 2005).

A falta de uma legislação e de estudos mais claros sobre abordagem policial contribuem para que as abordagens sejam vistas com desconfiança, gerando formas de insegurança que favorecem a intolerância e servindo de proteção para o surgimento de abusos policiais (Belli, 2016). Entender com mais clareza as decisões tomadas nas abordagens policiais trata-se de uma peça central no desfecho das ações policiais e entendimento das tomadas de decisão. Alguns estudos trazem luz a essas ações (Klahm \& Tillyer, 2010).

23 A importância da raça/etnia dos suspeitos em abordagem é marcada pelo grande número de estudos e análises nos últimos anos, em especial nos Estados Unidos, ocupando um papel central em pesquisas sociais. $O$ fator raça se mostrou relevante em abordagens, dada a histórica relação de violência entre as comunidades minoritárias latinas e negras - e a polícia (Klahm \& Tillyer, 2010). Em contrapartida, os defensores da polícia afirmam que não há estabelecida uma confiabilidade estatística que relacione a raça e o uso da força.

Nos últimos anos, a relação entre o sexo das pessoas abordadas também recebeu atenção. As análises mostram que os cidadãos do sexo masculino são mais abordados do que os cidadãos do sexo feminino. As pesquisas que estudam a relação entre a idade dos cidadãos abordados e o uso da força policial apontam que os agentes são menos propensos a abordar cidadãos idosos ou muito jovens (Klahm \& Tillyer, 2010).

\subsection{A situação e o contexto na atuação policial}

Os agentes policiais tomam suas decisões em ambientes dinâmicos. Assim, as dimensões tácita e corporificada surgem como suporte à tomada de decisão e ao julgamento, possibilitando que a atividade seja executada com habilidade e eficácia (Suss \& Ward, 2013). Para compreender com profundidade como a habilidade policial é construída ao longo do tempo, é importante analisar a relação existente entre a situação, as tomadas de decisão e os julgamentos, advindos das percepções dos policiais. Trata-se de um componente necessário à análise do trabalho e ao entendimento da prática profissional (Theureau, 2014).

26 Alguns estudos indicam que esses agentes, em situação de abordagem, são capazes de melhor julgar indícios - verbais ou não verbais - de mentira e suspeição do que a população civil o é (Ask \& Granhag, 2003; Vrij, 2000). Segundo Vrij (2000), militares experientes se tornam detectores de mentirosos à medida que absorvem experiências em suas ações.

27 Segundo Ribeiro (2013), profissionais que possuem tal habilidade são capazes de atuar e agir em meio a diversas situações - de problema ou não, de normalidade ou 
anormalidade, de segurança ou perigo -, trazendo maior eficiência aos processos organizacionais da corporação militar e à tomada de decisão policial.

Uma vez que há pouca ou nenhuma pesquisa no Brasil que aborde empiricamente o processo de tomada de decisão em ação de abordagem policial, um dos focos desta análise será trazer à luz aspectos das ações policiais que permanecem uma "caixapreta", alimentando as representações partilhadas na sociedade de que policiais agem movidos por preconceito de classe ou étnico. Um relato encontrado na literatura ilustra muito bem a complexidade da tomada de decisão na solução do dilema que consiste em abordar ou não abordar

“(...) Ao entardecer do dia... o meu parceiro e eu avistamos três membros de um gangue andando pela calçada, de costas para nós (...). Era evidente que eles estavam procurando um lugar para onde correr. Os dois rapazes nas extremidades dividiram-se... O cara do meio não sabia qual o caminho a percorrer e, simplesmente, congelou na nossa frente. Nós fomos para a direita quando paramos a, talvez, dez metros de distância. Como eu estava saindo da porta do passageiro do carro, ele começou a procurar algo na cintura com a mão direita. Então eu podia ver que ele estava chegando próximo da região da virilha. (...) Ele tentava chegar próximo da área da sua coxa esquerda, como se tentasse pegar algo que caía na perna da calça. Ele estava começando a virar-se para mim (...) Ele olhava diretamente para mim, e eu gritava com ele para não se mover: "Pare! Não se mexa! Não se mexa! Não se mexa!" (...) Como eu estava lhe dando ordens, eu tirei meu revólver. Quando cheguei a cerca de cinco metros do cara, ele veio com uma arma. Então, assim que sua mão chegou à área central do seu estômago, ele deixou cair a arma na calçada. Nós o levamos sob custódia..." (Klinger, 2004, p. 61, tradução livre).

29 Segundo Harris et al. (2006), policiais experientes, em situações de abordagem, tomam decisões adequadas, como, por exemplo, alvejar um abordado na tentativa de uso de arma de fogo. Isso sugere que o bom desempenho alcançado por esses agentes está relacionado com a capacidade dos militares de intuir situações futuras de agressão, e não somente com o treinamento teórico/tático (Conhecimento Oficial) e com a socialização que adquirem na academia.

Logo, a expertise de se fazer julgamentos e tomar decisões torna-se determinante para a aquisição de vantagens operacionais, porque esta expertise fornece elementos para a aplicação sensata das regras, criando, por vezes, novas regras quando necessárias e cumprindo com um importante papel na concretização das metas de prevenção institucionais da polícia militar (como diminuição de roubos, de assaltos, de homicídios, de agressões e de mortes) (Silva, 2004).

31 O expert está disponível às ações e as percepções que demandam o engajamento de si no uso de suas habilidades em função das exigências impostas no e pelo trabalho. A intuição floresce quando o indivíduo se mostra aberto e acessível às influências singulares do trabalho e das situações nas quais opera. Assim, tanto o sujeito escolhe as situações encontradas (através das experiências), quanto as situações encontradas o solicitam a agir (Merleau-Ponty, 1999).

o poder da situação por vezes é subestimado nesse agir intuitivo. A detecção da mentira é um excelente exemplo de tema em ciências sociais no qual o poder da situação é subestimado (Endsley, 1995). Assim, Blair et al. (2010) orientam que, para diminuir a influência dos vieses (criados pela não consideração da situação em pesquisas sobre a 
mentira) e, consequentemente, melhorar as chances de detecção de mentiras, deve-se considerar o contexto encontrado pelos policiais nos momentos em que as mentiras são ditas.

No mesmo sentido, Gladwell (2005) ressalta a importância de se analisar a atividade em situação, possibilitando ao indivíduo chegar a conclusões muito mais adequadas rapidamente. Para Matsumoto et al. (1993, in Castillo et al., 2012, p. 5), é importante que o policial se familiarize com o contexto onde trabalha para atuar de maneira mais dinâmica. Tal familiaridade com o contexto, o ajudaria a ajustar os detalhes que compõem sua tomada de decisão, não ficando preso a julgamentos prematuros.

Contudo, Bazarian (1986) citado por De Paula (2007), considera a intuição em situação apenas mais uma variável teórica pouco sólida e passageira. Nesse sentido, as teorias mais clássicas, próprias do cognitivismo e da lógica formal, defendidas por Bazarian, caracterizam-se por um foco míope dos estados psicológicos internos. Como resultado dessa lógica formal, as análises sobre a mentira têm procurado dados a respeito do tema em lugares menos adequados (ambientes controlados) (Blair et al., 2010). Apesar dos limites de análises em ambientes simulados, as pesquisas continuam, praticamente, na mesma direção, como nos estudos de Endsley (1995), onde os participantes são submetidos a ambientes simulados, ou como nos estudos de Zimmerman (2008) em ambiente controlado.

Portanto, com a inclusão da situação e do contexto, na análise deste artigo, espera-se que a capacidade de identificação cresça e o acerto na deteç̧ão de mentiras e suspeição seja mais preciso, possibilitando uma abordagem mais precisa. Assim, o objetivo deste estudo será o de descrever os fatores associados ao poder discricionário de polícia em ações de abordagem, por meio de observações em campo, analisando elementos do processo de tomada de decisão na seleção de pessoas em atitude suspeita. Os objetivos específicos podem ser delineados em três: $\left.1^{\text {}}\right)$ descrever o processo de abordagem, captando perspectivas e ampliando os casos em que o poder discricionário traria julgamentos em situação para identificar suspeitos e proteger a equipe; $2^{\circ}$ ) investigar o que influencia os julgamentos e percepções de policiais em situação de abordagem; e $3^{\circ}$ ) investigar o processo de tomada de decisão e julgamento.

\section{Percursos e definições metodológicos}

Este estudo foi desenvolvido na cidade de Itabira, Minas Gerais, onde, desde o século passado, as forças militares estão a serviço do estado. O efetivo de policiais acompanhou o crescimento urbano e soma hoje, aproximadamente,127 agentes em atividade. A sede do $26^{\circ}$ Batalhão da Polícia Militar, localizada nessa cidade, exerce responsabilidade territorial pelo policiamento ostensivo da ordem pública sobre 19 municípios, e suas dependências físicas - mais especificamente, o setor de treinamentos e procedimentos táticos - foram inicialmente utilizadas para apreciação nas análises gerais. Posteriormente, em análises mais profundas, foram apreciadas as abordagens executadas nas ruas e avenidas de Itabira.

Os agentes, policiais de trânsito analisados nesse estudo, são preparados pela academia militar e recebem instrução sobre legislação de trânsito e de técnicas e procedimentos operacionais voltados ao melhor desempenho tático e operacional, atuando em pontos 
previamente selecionados da cidade e estudados criteriosamente (baseando-se em estatísticas criminais e rotas de fuga), visando também à redução de índices criminais.

A presente pesquisa é classificada como qualitativa, com base observacional e corte transversal (Marconi \& Lakatos, 2003). O método de referência para a pesquisa é a análise ergonômica do trabalho (AET), de natureza qualitativo-descritiva, que se pauta em análises, visualizações e coletas de dados nos ambientes laborais, possibilitando compreender a atividade de trabalho executada do ponto de vista da microergonomia, ou seja, da atividade. $O$ método da AET exigiu que a pesquisa e a amostra fossem direcionadas de acordo com o que era apreendido no contexto de trabalho, por meio de bate-papo, contatos, conversas e vivências, captando verbalizações e situações presentes no dia a dia, de modo a perceber as inter-relações e as estratégias de tomada de decisão e julgamento dos policiais (Guérin et al., 2001).

Foram analisados os processos de tomada de decisão dos agentes militares e outros aspectos associados à sua atividade de abordagem, buscando entender em profundidade o contexto profissional estudado, atingir os objetivos estipulados e identificar os valores e significados da atividade que respondessem à problemática deste trabalho como avaliar e discriminar uma abordagem policial.

Os dados foram recolhidos no ambiente de trabalho dos agentes, utilizando-se para a coleta as técnicas de observação direta (observação participante) e entrevista em autoconfrontação. Foram unificadas diferentes etapas, nas quais os atores protagonistas foram confrontados sucessivamente com suas atividades - algumas vezes, diretamente no contexto de atuação; outras, nos dias subsequentes às filmagens das situações estudadas (Guérin et al., 2001).

41 A operação policial filmada é geralmente conhecida como blitz em pista de rolamento e pode ser dividida em três categorias diferentes, de acordo com seu foco: tipo 1, utilizada para campanhas educacionais; tipo 2, conhecida como corredor preventivo ostensivo, com foco no comportamento para seleção dos abordados; e tipo 3, convencional, com foco sobre os veículos. A mesma configuração poderá ser usada com diferentes objetivos.

42 A operação ora analisada é uma blitz da categoria tipo 2, que foi escolhida devido à ênfase dada pelos agentes sobre os indivíduos e seus comportamentos de suspeição e na qual se faz presente, de maneira mais relevante, o poder discricionário de polícia na seleção desses indivíduos. A filmagem possibilitou aos agentes analisados observar as potencialidades presentes na atividade por eles desempenhada, falar sobre elas e descrever seus próprios comportamentos.

Os atores filmados assumiram a tarefa de reviver a atividade para o pesquisador, aprofundando questões que surgiam no desenrolar da análise (cf. Tabela 3). 
Tabela 3 : Dez pontos centrais emersos da atividade policial

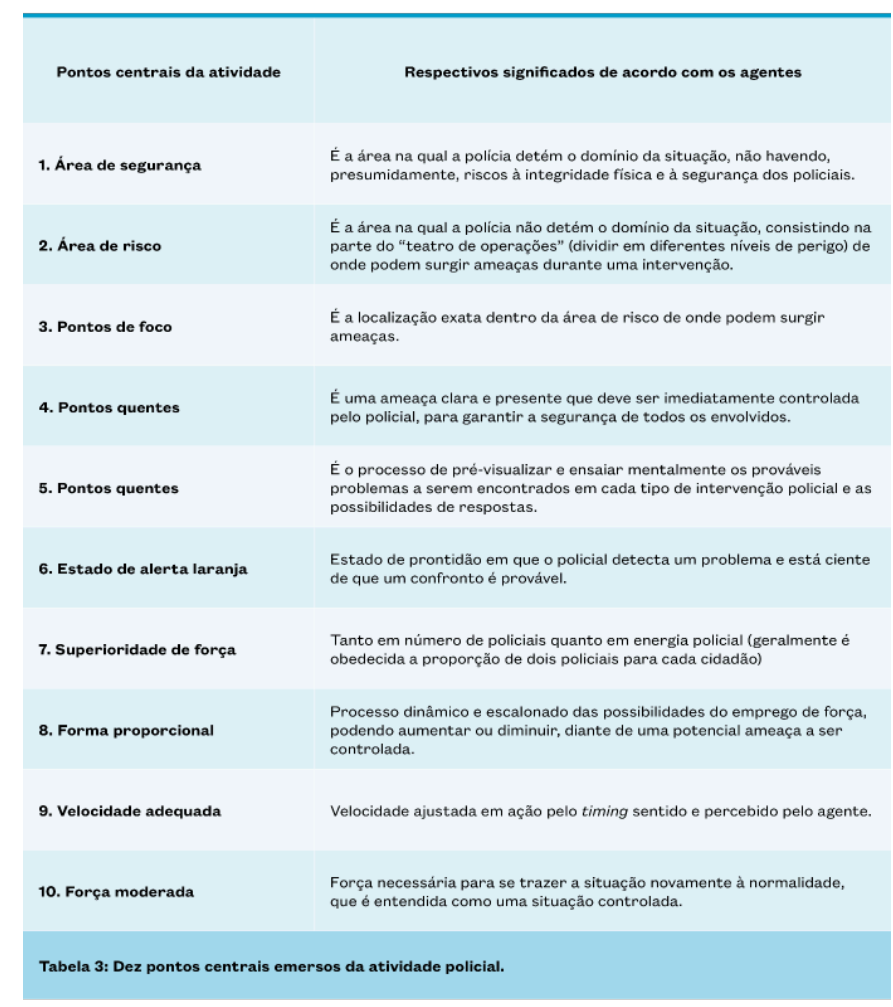

Tabela 3 : Dez pontos centrais emersos da atividade policial

44 Segundo Theureau (2014), por meio da entrevista em autoconfrontação, pode-se acessar a consciência pré-reflexiva dos atores, aquela que vigora no desdobramento da ação, no desenrolar da atividade. Assim, tal técnica possibilita entender como os policiais agem, percebem e utilizam recursos para atingir seus objetivos em situações reais de trabalho.

No processo de autoconfrontação, a análise, inicialmente, tem por objetivo situar o sujeito o mais próximo possível da situação real de trabalho, com suas particularidades e singularidades. Posteriormente, pretende compreender com mais profundidade os motivos pelos quais o sujeito adotou os comportamentos observados.

Para a autoconfrontação, foram convidados policiais que trabalham em uma base comunitária móvel (BCM) (Tabela 4). A oportunidade de acompanhá-los se deu pela preocupação da corporação para com a integridade física do pesquisador, que, segundo eles, não poderia acompanhar uma viatura em ronda, pois estaria se expondo ao risco desnecessariamente. As informações correspondentes às patentes, ao tempo de atuação profissional e ao período de autoconfrontação estão contidas na tabela a seguir. 
Tabela 4 : Participantes da autoconfrontação

\begin{tabular}{|c|c|c|c|c|}
\hline \multirow{2}{*}{ Patente/função } & \multirow{2}{*}{$\begin{array}{l}\text { Tempo aproximado de } \\
\text { atuação profissional }\end{array}$} & \multicolumn{3}{|c|}{$\begin{array}{l}\text { Periodo de autoconfrontação } \\
\left(1^{\mathrm{a}}, 2^{\mathrm{a}} \text { e } 3^{\mathrm{a}} \text { autoconfrontações }\right)\end{array}$} \\
\hline & & 1 & $2^{\mathrm{a}}$ & 3 \\
\hline $\begin{array}{c}1^{\circ} \text { Sargento (SGR) } \\
\text { (Vistoriador) }\end{array}$ & 30 anos & $1 \mathrm{~h}$ & $50 \mathrm{~min}$ & $50 \mathrm{~min}$ \\
\hline $\begin{array}{c}1^{\circ} \text { Sargento (SGR) } \\
\text { (balizador/selecionador) }\end{array}$ & 23 anos & $1,2 \mathrm{~h}$ & $40 \mathrm{~min}$ & $50 \mathrm{~min}$ \\
\hline
\end{tabular}

Tabela 4 : Participantes da autoconfrontação

\section{Análise da abordagem em ação: o vídeo trazendo confrontos}

"Olha, o que faz a gente escolher são as atitudes"

Balizador entrevistado

A análise apresentada nessa seção é uma descrição de características atribuídas como suspeitas pelos policiais participantes. As características e convenções sociais construídas definem o modo de vida dos agentes em ação. Portanto, quando se analisa uma forma de vida, se deve fazer um exame detalhado dos comportamentos em ação, procurando entender o que os motivou e quais informações são relevantes do ponto de visto do profissional naquele momento. Esse é o objetivo dessa seção. Vale ressaltar que as funções são previamente determinadas, baseando-se em partes tácitas e partes prescritas.

Assim, a decisão de parar um veículo exige do policial balizador (policial responsável em selecionar os carros que devem ser verificados) a habilidade de detectar traços de suspeição nos indivíduos. Tais traços são comportamentos, características e movimentos, às vezes sutis, considerados pelo agente como indícios de nervosismo ou de medo e que representam, a seus olhos, motivo de desconfiança. Considerando-se a subjetividade envolvida na seleção desses indivíduos, a atividade do balizador torna-se complicada de ser realizada.

Segundo o balizador entrevistado, dentro dos limites da operação - que, para ele, não se restringem à área localizada entre os cones (cf. Figura 1) -, há uma faixa em que sua atividade de detecção pode ser melhor executada: "daqui, nós [balizadores] temos um campo bom de visão em relação aos carros que vêm. Pela minha visualização, já se começa a ter um pouquinho de 'maldade' [cujo significado será explicado mais adiante]".

o balizador permanece a maior parte do tempo em que realiza sua atividade nesse lugar, posicionado sobre a faixa central e andando de um lado para o outro. Como se caminhasse sobre uma linha imaginária, ele não se afasta dali. Ora anda na direção dos carros que se aproximam, distanciando-se da equipe, ora anda na direção dos seus colegas, distanciando-se dos carros, sempre com a intenção de proporcionar segurança à equipe: "é [necessário que seja] um local que consiga dar segurança a toda a equipe". 
Figura 1 : Posição do balizador no centro da pista de rolamento (acervodo autor, 2016)

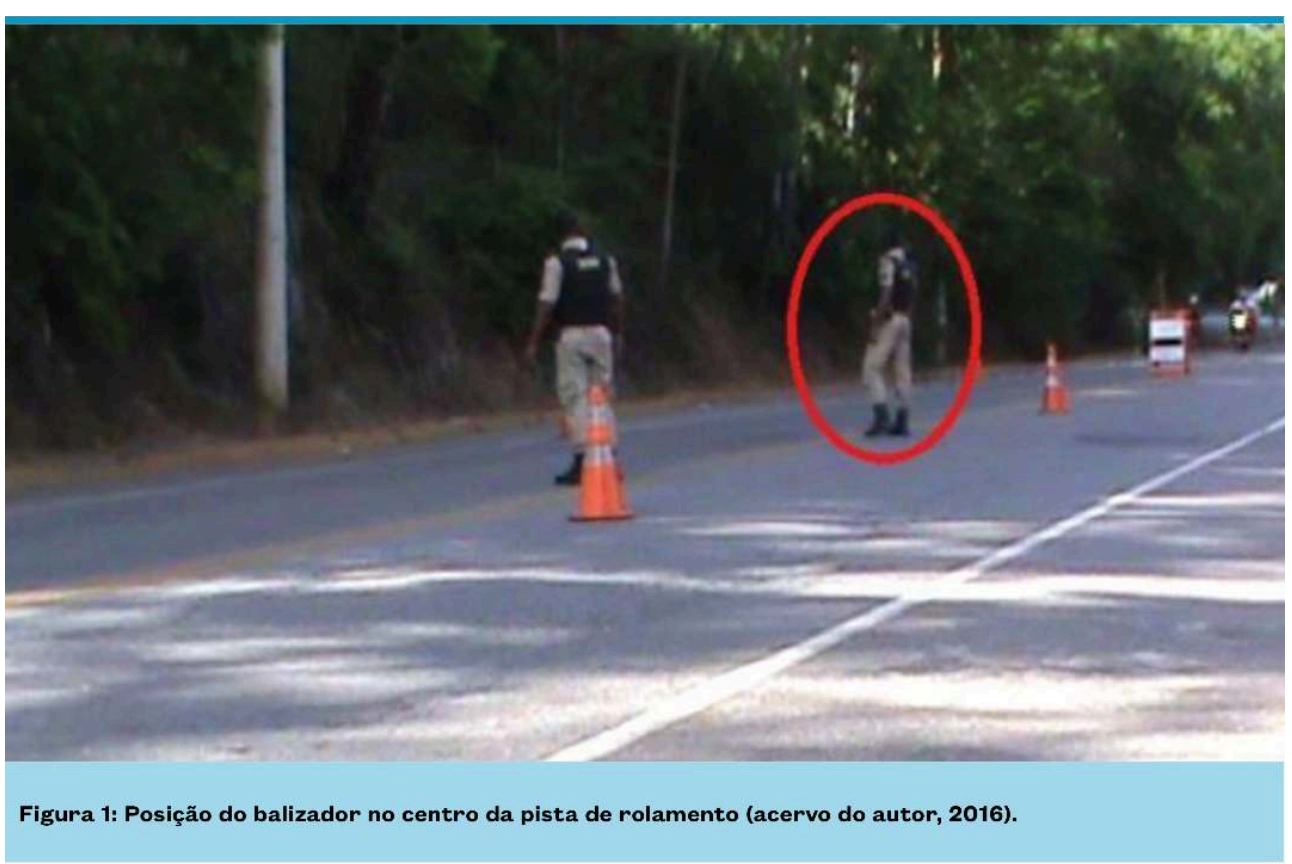

Figura 1 : Posição do balizador no centro da pista de rolamento (acervodo autor, 2016)

51 Analisando-se as falas do balizador, nota-se que a posição do agente na abordagem é fundamental para estabelecer um campo de visão significativo em relação aos abordados e à própria equipe, dado que isso possibilita com que ele perceba detalhes sobre o outro, resultando ou não em suspeição. A habilidade de perceber tais detalhes é entendida pelo agente como "maldade".

Segundo o balizador, o campo de visão significativo "possibilita dar segurança a toda a equipe". Nesse primeiro contato, sua atenção é direcionada a dois pontos principais: os colegas de equipe e os veículos que se aproximam: "olha o que eu faço. Sempre tenho que ficar atento com a minha retaguarda, com quem está chegando. Tenho de ter visualização dos PMs e dos veículos". Percebe-se que, ao analisar o contexto, ele permanece olhando, por algum tempo, para cada ponto e reexamina suas observações constantemente, julgando-as a partir de sua própria percepção.

o balizador atribui a essa posição o título de "lugar ideal", que garante, caso necessário, o ajuste de foco. Na entrevista em autoconfrontação, ele explica a importância de tal posição e sua preferência por ela devido à boa visualização que ela oferece. Para o agente, esse lugar é o ponto onde sua atenção pode ser melhor direcionada quando solicitada pelos membros da equipe ou pelos veículos que se aproximam, evitando que sua visão permaneça em um único foco.

o balizador, constantemente, aponta para o vídeo, indicando que, quando quer visualizar melhor os carros, dirige-se ao primeiro cone e, quando quer visualizar melhor os abordados, dirige-se na direção dos colegas. Ele relata o seguinte sobre esse dado: "onde eu posso olhar para todas as pessoas envolvidas na operação, sem nunca ficar com a visão em foco. Por exemplo, só olhando [a partir] desse carro. Se você reparar, eu sempre fico andando de um lado para o outro, e isso é para poder ver melhor". Para descrever esse lugar, ele verbaliza. 
"Repara no lugar em que eu estou. Eu estou do lado esquerdo da pista, afastado, em cima da faixa central. Este é o local ideal, de onde consigo ver os veículos que estão chegando, os PMs e a minha retaguarda. Repara que eu fico girando e olhando a todo momento os carros, os abordados, os pedestres, o mato. Se reparar bem, eu não fico olhando em uma única direção". parada do cidadão motociclista que havia sido abordado em determinado momento da operação se deveram a seu julgamento, que lhe indicou motivos de suspeição: "o fato de parar e escolher essa moto, eu a escolhi porque ela me gerou suspeição no momento". Para ele, a seleção se baseia em critérios de relevância advindos das percepções geradas sobre as reações dos cidadãos. Somente a partir dessa percepção, o agente seleciona o Ele observa que seus colegas vistoriadores, ao contrário dele, ficam presos em um único foco, deixando de lado o contexto. Segundo ele, “visão em foco é você ficar olhando só para o indivíduo abordado, como no caso dos vistoriadores (policial responsável em verificar os carros selecionados para parar). Se você reparar, vai ver. Olha os policiais que estão falando com os condutores. Eles estão focados conversando com o condutor, nem observam o resto".

Devido a essa percepção, o balizador atribui a si mesmo a função de garantir a segurança dos colegas policiais, dado que estes se apresentam, de acordo com ele, sem atenção ao contexto. Essa falta de atenção ao contexto se deve à confiança que se têm na equipe, de modo a saber que podem deixar-se envolver com a abordagem enquanto outros "assistem" ao contexto para ele. Esse senso de equipe se desenvolve no tempo à medida que são vivenciadas situações que confirmem a habilidade do agente em proteger e perceber situações de potencial agressão ou suspeição (confirmadas pelos casos positivos encontrados).

7 Entretanto, o ônus dessa organização real é que quando há mudança na equipe, em especial do balizador, perdesse essa confiança. Desviando a atenção dos policiais da vistoria para a segurança da equipe. Isso faz com que o agente direcione toda sua atenção ao ponto por ele chamado de "resto" à medida que o contexto solicita, e, ao mesmo tempo, deixa de lado outros. Em outras situações, isso se repete. Ele descreve seu comportamento indicando que, quando todos os vistoriadores estavam ocupados, sua atenção se voltou para a proteção deles e, quando não estavam necessariamente vistoriando, sua atenção se voltou para os carros que então se aproximavam.

Assim, o balizador se concentra em um recorte do contexto que lhe é apresentado. Ele é solicitado a buscar determinados pontos e, à medida que o faz, concentra-se tanto em alguns, que acaba se esquecendo de outros. 0 agente prioriza alguns pontos suspeitos, deixa outros de lado e seleciona determinados problemas a serem resolvidos: "eu estou olhando para os carros que estão vindo, quem está passando atrás, os ocupantes dos veículos. Como aqui é um lugar de mata, tenho de olhar para o mato, lugar de onde pode vir alguma agressão. Nunca manter um único foco, senão pode acontecer fuga". Questionado sobre o que o faz priorizar determinados pontos enquanto deixa outros momentaneamente de lado, o agente me indicou os momentos em que sua atenção foi requerida e as direções de sua perspectiva.

A respeito dos veículos que se aproximavam, o balizador verbalizou que a escolha e a
sobre as reaçôes dos cidadãos. Somente a partir dessa percepção, o agente seleciona o

Laboreal, Volume $17 \mathrm{~N}^{\circ} 1$ | 2021 
veículo: “tenho que definir se aquele suspeito que esteja vindo é 'bom', [se] compensa abordá-lo ou não, se não esboçou nenhuma reação de medo ou nervosismo...".

o balizador perece acostumado a selecionar os cidadãos abordados: "agente vai pegando as 'maldades' da seleção". A "maldade” o faz se atentar aos movimentos e traços de nervosismo, comparando constantemente o que é visto com suas experiências e vivências. Em um movimento de inclusão e exclusão de pontos, recomeça o ciclo de análise a cada nova sequência de seleção, sobre cada veículo que passa diante dele. Nesse sentido, reforçando o que já foi dito, a "maldade" é entendida como a habilidade de selecionar os chamados "suspeitos bons".

61 Na perspectiva do agente, "suspeito bom" é aquele que esboça alguma reação estranha no momento em que visualiza a operação: "ele viu a blitz, eu vi. Ele foi e deu aquela reduzida atrás do carro. Se você reparar aqui, você vai conseguir ver essas movimentações. Você sente aquela 'tremida', aquela 'escondida'. Quando eu percebo isso, eu já dou o sinal para abordar". A seguir, é representado o movimento de "escondida", considerado pelo agente como uma reação que levou à suspeição em relação ao condutor e à sua consequente parada (Figura 2).

Figura 2 : Movimento de suspeição chamado de " escondida » (acervo do autor, 2016)

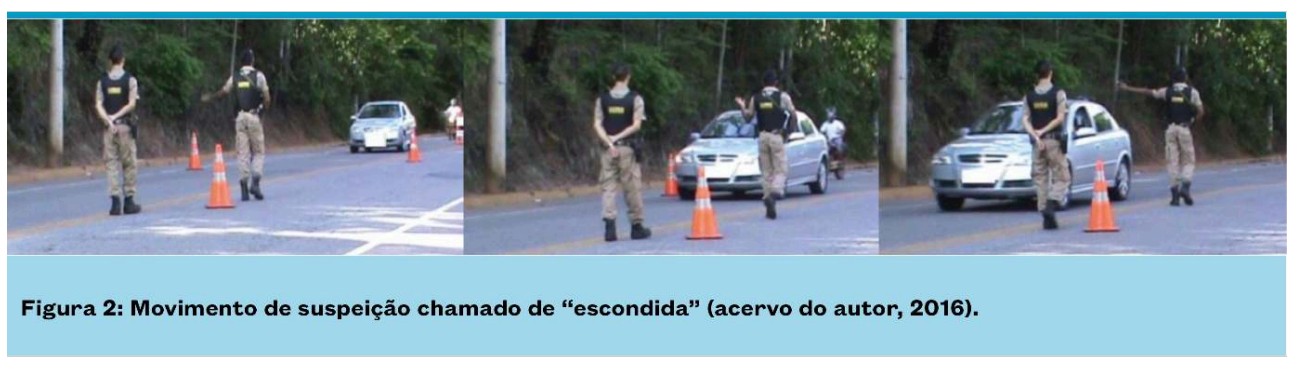

Figura 2 : Movimento de suspeição chamado de « escondida » (acervo do autor, 2016)

O pesquisador, outra vez, interpela o balizador sobre o aspecto "sentir" por ele verbalizado. Observando com atenção exatamente um momento que solicita tal aspecto, o agente explica: "é perceber a reação do camarada quando ele está chegando na operação, aprender a selecionar a pessoa". Pode-se entender que sinais ou estímulos perceptuais solicitam sua atenção. Quando esses sinais são confrontados, emerge a relevância entre o observado pelo pesquisador e o percebido pelo agente. Vale ressaltar que, sem a orientação do balizador, indicando ao investigador o que olhar, este não saberia o que ver nas cenas.

63 Para o balizador, o motociclista selecionado emitiu um sinal: "a pessoa dá um sinal, você sente". De alguma forma, o agente atribuiu sentido e significado a esse sinal, que foi ganhando outros contornos à medida que novos indícios surgiam. Ensinando o pesquisador a olhar, ele o convida a ver o que ele vê: "se você olhar aqui [apontado para o vídeo] ... Olha a freada. [0 abordado] não sabe se vai ou se volta. Olha o cara freando. Aí, está vendo? [O abordado] não reduz. Não sabe o que faz. Escondendo-se... Esse tipo de comportamento, temos de ver".

64 São muitos os detalhes que o balizador tem de perceber ao selecionar: freadas bruscas, erros de marcha, "afogamentos" e "escondida" de veículos, movimentos suspeitos dentro dos carros. Quando o policial se deparou com um desses deslizes, selecionou o motoqueiro, que, para ele, demonstrou nervosismo e desconforto. $O$ agente verbaliza 
sobre o caso: "olha esse motoqueiro [apontando para o vídeo]. Pelo nervosismo que eu senti [nele], eu o parei. E por isso ele vai ser parado, para [eu] saber o que está acontecendo".

A sequência do processo decisório do policial consiste numa escala de percepções que vão se somando, a começar pelo primeiro contato visual, "quando ele [o abordado] avista o cone [que indica haver blitz]". Em seguida, o agente passa a constantemente observar o outro, procurando sinais que indiquem ou classifiquem o abordado como "bom". Foi assim que ele logo percebeu que o motoqueiro abordado apresentava traços de suspeição: "você vê que ele [o motoqueiro abordado] deu aquela 'manota', não diminuiu a velocidade, já veio na pressão, 'vou passar, vou passar', escondendo-se".

Segundo o balizador, quando os abordados trazem consigo materiais ilícitos, os sinais que os indicam são muito mais evidentes, dada a pressão psicológica sofrida pela pessoa em vias de cometer ato criminoso: "se ele [o abordado] estivesse com droga, arma ou qualquer coisa, a pressão seria tanta que o cara travaria todo". Uma vez que, no caso, o traço percebido não foi, em sua perspectiva, tão discrepante, de imediato foi possível induzir que o abordado não portava nenhum ilícito, o que resultou apenas em uma abordagem para verificação: "fui eu que fui abordá-lo. Olha a adrenalina do cara. "Isso vai gerar uma abordagem'. Eu vi que ele visualizou, já teve aquela atitude".

Segundo o balizador, a seleção se deu por dois motivos: os indícios que emergiram quando o abordado viu o cone, e o modelo da moto que ele conduzia (Honda XRE-300). De acordo com o agente, esse modelo é muito recorrente em furtos na cidade. Na autoconfrontação, o policial me apresentou um exemplo para me explicar essa relação.

"Vi [em outra situação] um cara de moto [do mesmo modelo]. Ele fez a rotatória certinho e desceu em direção à rodoviária. Mas eu cismei. Eu o segui e parei a moto. "Alguma coisa de errado tem". Quando fomos ver, [a moto estava] sem lacre de placa. E isso [essa percepção], só com o tempo. Tirocínio é como se fosse uma intuição. Cidadão comum, quando fica andando, geralmente ele não presta muito a atenção nas mãos, na cintura, no movimento. Nós, os policiais, somos totalmente o contrário. A nossa mente passa a ser condicionada a buscar algo com que as pessoas de bem [civis] não tem preocupação".

68 Ao abordar o motociclista, o balizador se deparou com a seguinte configuração. Havia dois veículos abordados mais uma moto. Contudo, não havia policiais para vistoriar o motociclista, a não ser o próprio balizador (cf. Figura 3), o que fez com que ele decidisse atuar diretamente na abordagem ao motociclista.

Para o balizador, sua atividade é a função mais difícil envolvida na operação, dado que, além de selecionar os veículos que irão parar, há atribuições simultâneas, como ser o "segurança da equipe" e o "auxiliar dos vistoriadores". Isso pode ser percebido em sua verbalização: "eles [os colegas vistoriadores] estão abordando aquele carro, e eu abordei esta moto, sozinho. Então, eu auxiliei em mais uma abordagem". Segundo o agente, seu deslocamento sobre a faixa central é decorrente dessa dupla finalidade. A seguinte verbalização, extraída de sua autoconfrontação, deixa claras as funções pelas quais o balizador é responsável e o papel da equipe durante a operação.

"Eu sou o segurança de toda a equipe. Eu auxilio na seleção de todos os suspeitos. Todo mundo já tem o seu papel bem definido. Fica mais fácil de a gente trabalhar assim. A equipe é experiente, já sabe trabalhar. Então ele [apontando para o colega] já tem um papel definido. Não é preciso ficar mandando mais. Treinamos ao ponto de fazermos [a operação] pelo hábito. 
Eu fico especialmente aqui, nessa área de abordagem [mostrando o centro da pista], porque é uma área em que pode ter um conflito e, posso prestar atenção ao redor deles".

Figura 3 : Direção do olhar segundo a expressão « ao redor deles (acervo do autor, 2016)

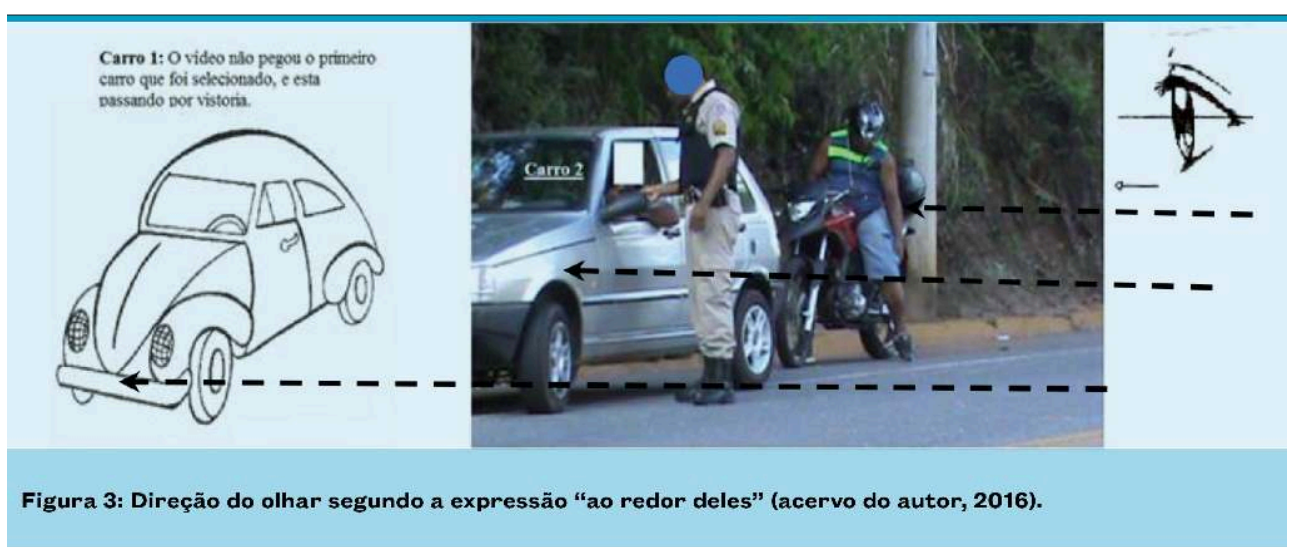

Figura 3 : Direção do olhar segundo a expressão « ao redor deles (acervo do autor, 2016

70 Segundo o balizador, a decisão de atuar, naquela situação, como vistoriador se deu por duas razões: primeiro, porque ele se julgava no dever de proteger seus colegas de operação, como se percebe na fala: "nesse caso, eu não podia deixá-los sozinhos [os policiais]. Olha a equipe de costas para o abordado, sem proteção alguma"; segundo, porque ele visava "aumentar seu desconforto" [do abordado] (Figura 4).

Figura 4 : Pontos de atenção ao ver o cidadão abordado (acervo do autor, 2016)

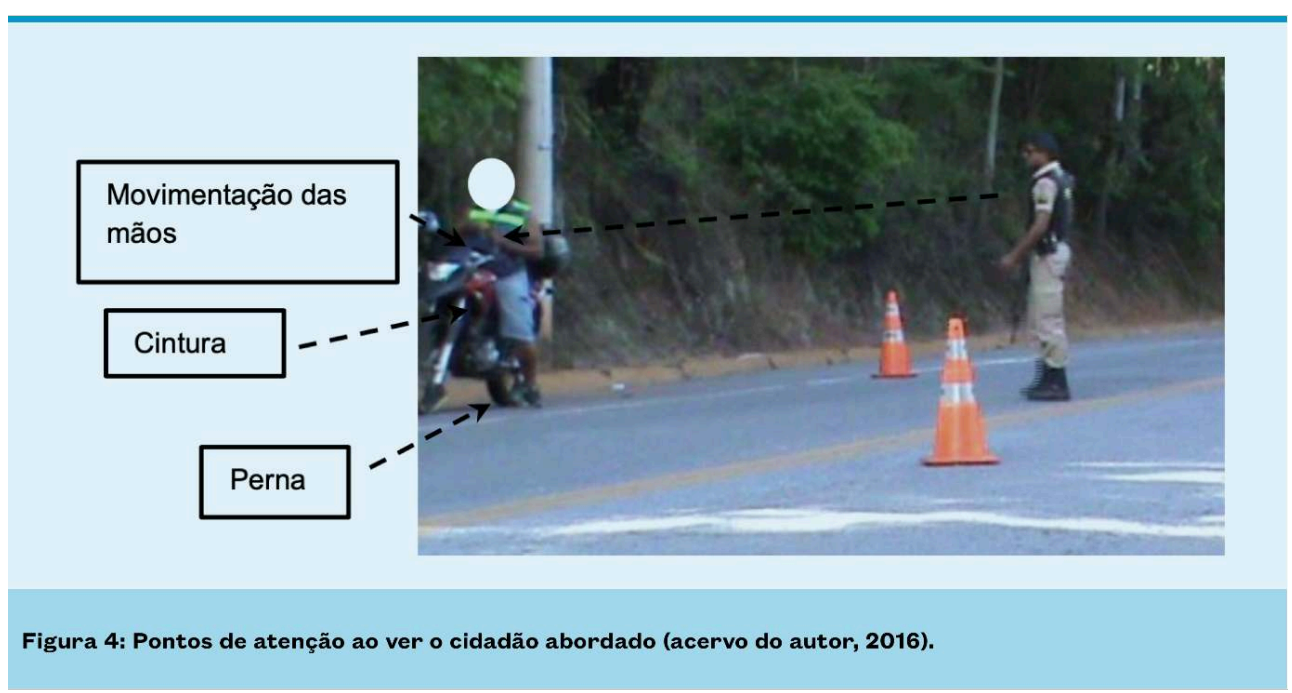

Figura 4 : Pontos de atenção ao ver o cidadão abordado (acervo do autor, 2016)

71 Foi perguntado ao balizador o que ele olhava e o que via no abordado, nesse momento $\mathrm{da}$ abordagem. $\mathrm{O}$ agente indica que, nesse caso em específico, ele imediatamente excluiu a presença de arma e de volumes suspeitos em posse do abordado, dada sua vestimenta: "nesse caso, como está de moto, eu já vi a vestimenta, a postura... Praticamente impossível de estar armado. Você já olha e já identifica”. A cintura e as mãos foram os pontos que o fizeram perceber esse dado. 

permanece com o olhar fixado no abordado: "até ver [ter certeza] se o cara é de bem mesmo... Não sei se você reparou, mas eu não tiro o olho [de cima] dele. Sempre atento". Aqui, ele não mais é um balizador, mas um vistoriador, que assumiu essa função priorizando a segurança dos colegas que estavam ocupados.

Quando vai ao encontro do motociclista, seu colega vistoriador, que acabara de realizar sua atividade precípua, percebe, de algum modo, a falha na configuração da equipe e, por isso, assume a posição de balizador. Essa mudança de função no curso da abordagem fez com que houvesse mudanças na movimentação, com o objetivo de, na perspectiva do balizador, manter a segurança da operação: "eu auxiliei em mais uma abordagem, mas repara que esse outro policial [apontando para o vídeo] já vem e toma a postura de segurança no meu lugar". A segurança aparece como uma regulação coletiva, em que a gestão de risco é compartilhada pelo balizador e pelo vistoriador. O interessante é que esse movimento aconteceu sem diálogo ou sinal entre os agentes (cf. Figura 5). E a segurança, em questão, se dá para a segurança da equipe, deflagrando outro valor prioritário, que é a priorização da integridade da equipe, antes da própria vistoria.

O auxílio é, para o balizador, um ponto crucial para a segurança dos companheiros. 0 agente descreve que sua movimentação e de seus colegas foi decisiva na garantia de sucesso da operação: “(...) repara que esse outro policial já vem e toma a postura de segurança no meu lugar. Sempre, abordagem com segurança é o nosso foco". Nesse sentido, para se realizar uma boa operação, são necessárias, segundo o policial, "tranquilidade" e "técnica": "toda a atividade que a gente está realizando é pautada pela técnica, mas sem afobação, porque, nesse serviço, a gente não tem que ter pressa, tem que ter paciência".

Figura 5 : Movimentação do balizador e do vistoriador objetivando a segurança (acervo do autor, 2016)

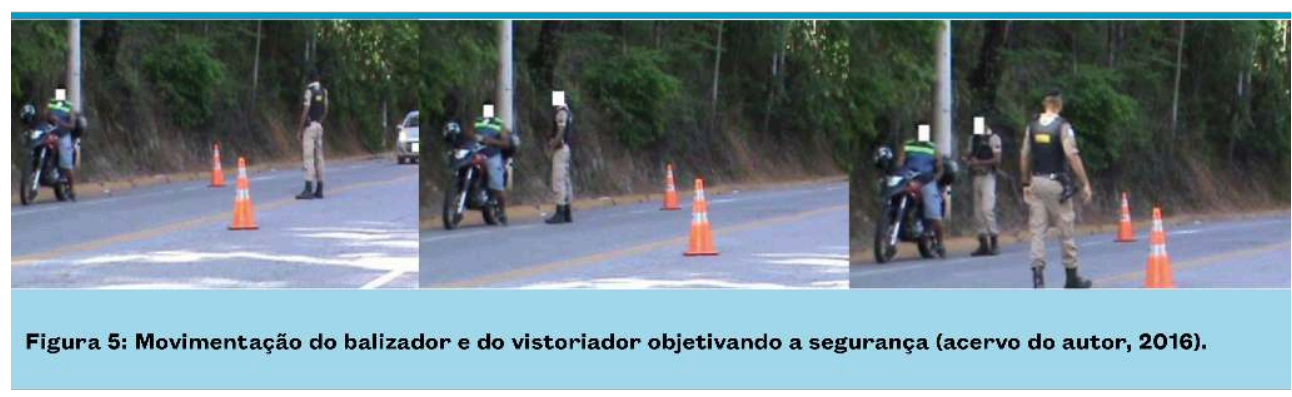

Figura 5 : Movimentação do balizador e do vistoriador objetivando a segurança (acervo do autor, 2016)

75 Como dito, o balizador, nesse momento, tem toda sua atenção voltada para o motociclista. Aspectos como jeito, mãos e corpo do abordado são pontos de atenção explicitados nas autoconfrontações. Segundo ele, na conversa que teve com o cidadão, este não apresentou mãos trêmulas ou falas pastosas quando lhe foi solicitada a apresentação dos documentos, o que indicou ao agente sobriedade e tranquilidade, diminuindo suas suspeições e culminando na descaracterização da suspeita, após a verificação dos documentos e leitura da placa. 
Nesse momento, sua atenção se volta novamente para os carros que se aproximam, excluindo o motociclista como ponto de atenção, e ele retorna à atividade de balizador (Figura 6).

Figura 6 : Olhando a aproximação dos carros (acervo do autor, 2016)

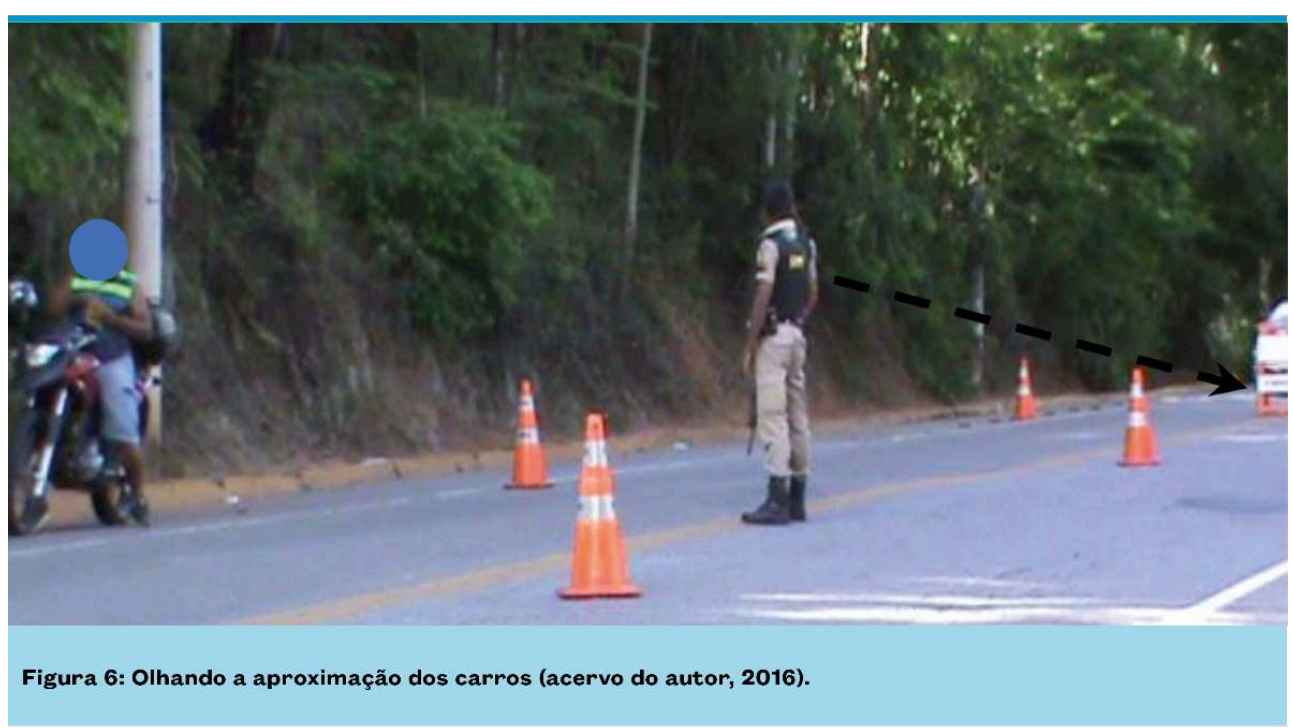

Figura 6 : Olhando a aproximação dos carros (acervo do autor, 2016)

O veículo que se aproxima da operação, desta vez, é um carro. O agente verbaliza: "depois de auxiliar meus colegas, agora eu volto para a posição de balizador... definir se aquele carro que está vindo é 'bom' para parar”. Logo, ele retorna à posição assumida no centro da pista, indo em direção aos colegas, dado que, para ele, é uma posição que melhor se adequa à verificação dos carros que se aproximam. Contudo, a análise dos comportamentos que acontecem dentro de veículos é vista por ele como de mais difícil realização e o erro na seleção, mais comum (na autoconfrontação, como era de se esperar, o balizador também apresentou dificuldades na leitura de indícios de suspeição nos condutores. Essa dificuldade o fez se lembrar da importância de sua posição, uma vez que esta favorece a visualização dos ocupantes.)

78 A dificuldade de observação leva o balizador a adotar outra estratégia de seleção. Assim, ele escolhe o veículo vermelho observando os seguintes critérios: quantidade, sexo e idade dos ocupantes. Segundo o agente, "três, quatro pessoas dentro do carro, que não deu para eu ver de longe, então eu tive de parar aquele carro para ver... Às vezes, eu já vejo um carro vindo com uma mulher, ao lado um senhor ou uma criança. Então eu não vou parar esse carro. Mas, neste caso, eram três caras". Contudo, surge outro carro com diversos homens, e ele decide não pará-lo. Quando questionado, o policial verbaliza: "agora eu não vou parar mais do que dois veículos. O nosso número é reduzido". Ainda segundo ele,

"Eu mantenho um ou dois carros, no máximo, pois tenho segurança de estar visualizando [o contexto], porque eu sou o segurança deles [os meus colegas de operação]. Eles estão com a atenção voltada para os carros. Eles não têm essa segurança. Essa segurança, quem a dá sou eu. Eu estou ali para fazer a segurança deles". 
Por um breve momento, não passam mais veículos na pista de rolamento, e o balizador olha para o mato (Figura 7). Quando perguntado sobre o que lhe chamou a atenção, ele descreveu: "ouvi um barulho no mato. Era um galho que estava quebrado. Mas a gente tem que ficar esperta. A gente é acostumada a ficar assim. Alerta laranja".

Figura 7 : Olhando o mato (acervo do autor, 2016)

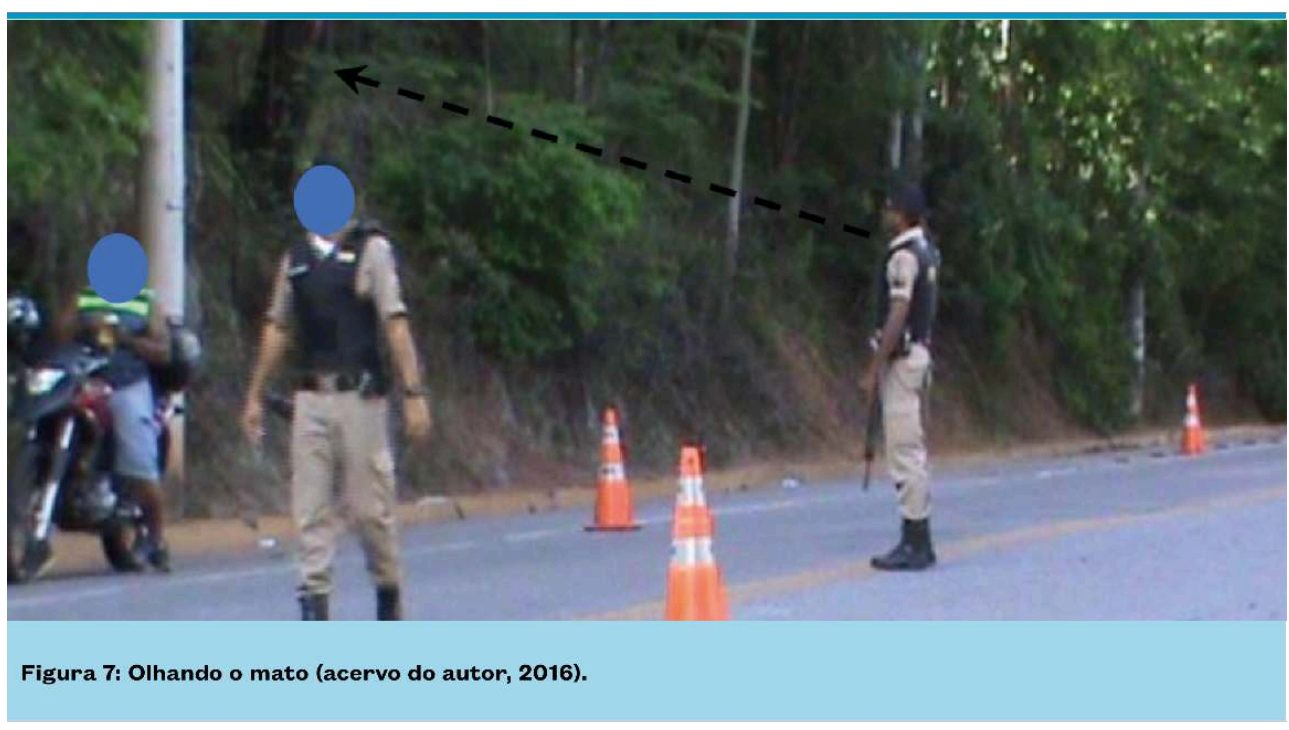

Figura 7 : Olhando o mato (acervo do autor, 2016)

Como o balizador acabou de descartar o motociclista abordado como suspeito, o barulho do mato como ameaça, e não há carros se aproximando, sua atenção é direcionada para outro ponto, os pedestres (Figura 8). Num deles, chamaram a atenção do agente o uso de "calça tactel" e "chinelo havaiana" e a "mão fechada". De acordo com o policial, esse tipo de vestimenta é recorrente entre usuários e traficantes de drogas da cidade. Ele relata que não havia percebido no pedestre nenhum movimento ou ocultação que lhe solicitasse fazer uma abordagem, mas decidiu observá-lo por um momento, analisando-o, para descobrir suas intenções:

"Costuma a pessoa estar andando e com a mão fechada, você [enquanto policial] imagina que tem uma bucha de maconha. Esses dias, estava em patrulhamento e flagrei um cara com a mão assim. Na hora em que eu o enquadrei [ordenando] "mãos na cabeça!", o cara [estava] com a mão cheia de pontos. Ele estava ficando mais com as mãos fechadas, dando a entender que talvez tivesse alguma coisa, mas o cara não tinha nada. Você pode me perguntar: "então tudo que você vê com a mão fechada vai te gerar suspeição?”. Eu te respondo: não. São tipos de situações em que você vai acabar abordando: cabelinho amarelo, sobrancelha talhada... Pode até não ser [bandido], mas acaba assumindo um ar de suspeito". 
Figura 8 : Policial observando os pedestres (acervo do autor, 2016)

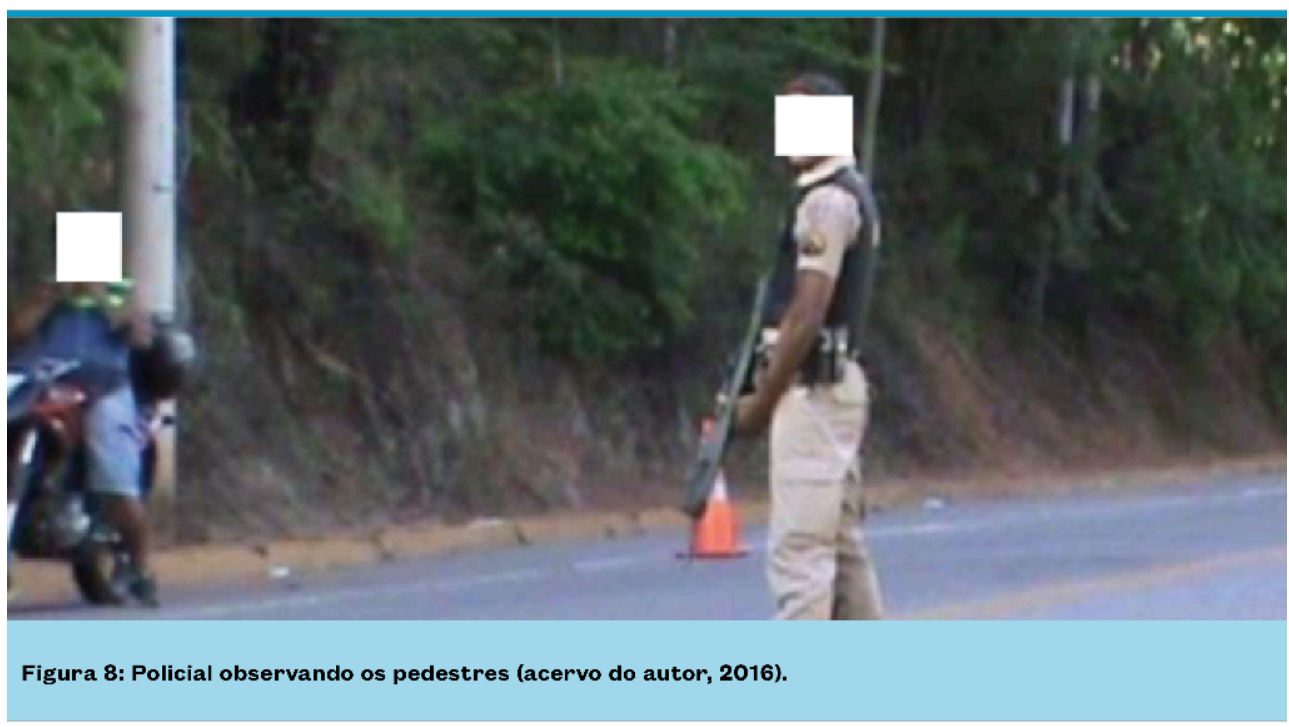

Figura 8 : Policial observando os pedestres (acervo do autor, 2016) vistoria por ele desenvolvido, destacando os pontos de suspeição mais relevantes no que diz respeito a seu julgamento perceptivo. De acordo com suas verbalizações, a atividade por ele desempenhada auxilia coletivamente na operação. Segundo o agente, a posição que ele assume na operação é fundamental para a segurança da atividade, dado que, no momento da aproximação de veículos, adquire condições posturais que possibilitam a identificação de gestos tidos como suspeitos: "na verdade, essa posição que assumo é uma posição segura. É para a gente conseguir selecionar os indivíduos suspeitos. É uma postura mais para segurança mesmo".

Figura 9 : Vistoriador $2: 3^{\circ}$ sargento 7, com vinte anos de profissão (acervo do autor, 2016)

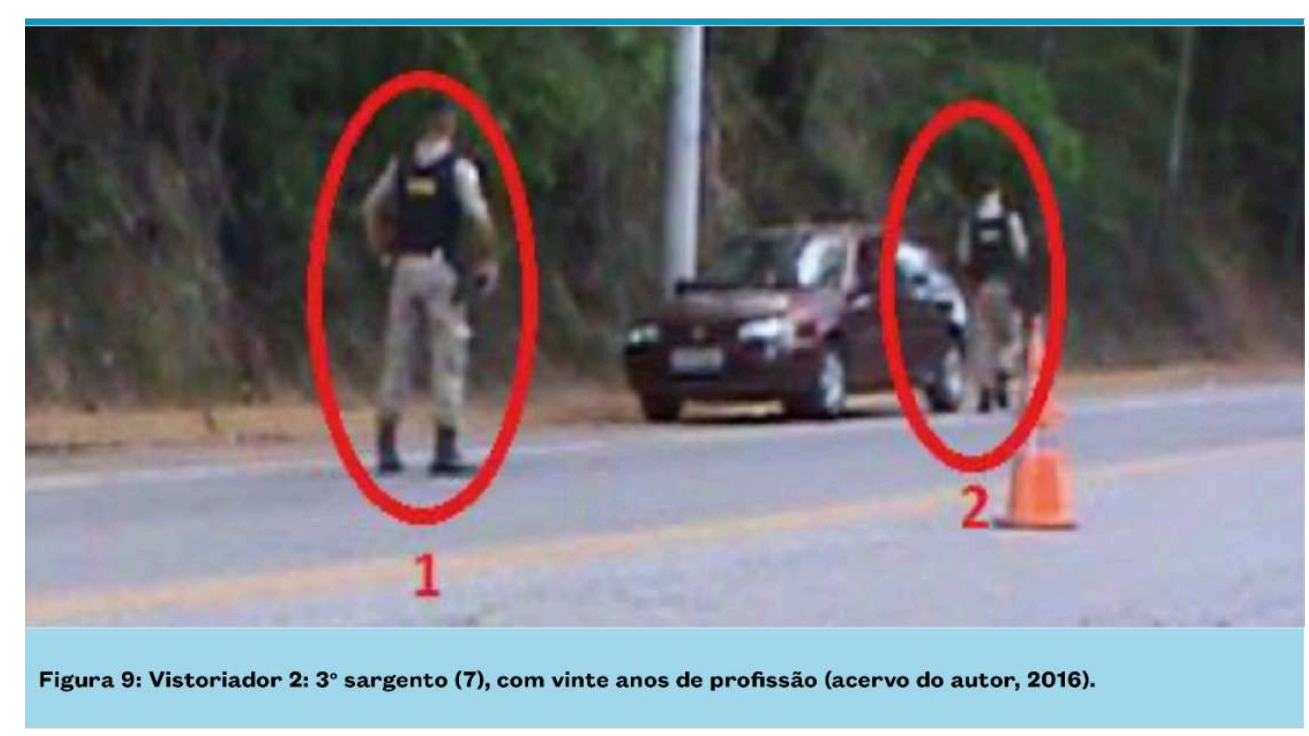

Figura 9 : Vistoriador $2: 3^{\circ}$ sargento 7, com vinte anos de profissão (acervo do autor, 2016) 
O vistoriador, assim como o balizador, estabelece uma linha média sobre a qual permanece durante toda a atividade. O sentido de aproximação, para ele, é da parte de trás para a da frente do carro e lhe possibilita visualizar o motorista e os gestos que este executa: "se você notar, esta posição me possibilita ver toda a operação policial, além de me permitir visualizar dentro dos veículos, os ocupantes". Vale ressaltar que não se tratam de prescrições formais, aprendidas com a formação profissional, mas sim de saberes desenvolvidos e partilhados. Em especial, a direção do olhar.

Segundo o vistoriador, a posição final do seu movimento é localizada entre as duas portas do veículo. $O$ agente verbaliza que não espera até chegar a essa posição, ao lado do veículo, para começar a observá-lo. Como em uma operação de fatiamento com o olhar, o policial acompanha uma sequência de "pontos de atenção", constituídos pelo assoalho do banco traseiro do veículo, pelo seu porta-luvas e pelas mãos do motorista: "quando estou vindo [em direção ao veículo], eu já vou analisando essas coisas, as mãos do motorista, o banco e assoalho traseiros, o porta-luvas também é um lugar de grande perigo, pode ter armas".

Além de possibilitar a visualização por fatiamento, a posição assumida pelo vistoriador, na barra central, é, segundo o agente, "confortável" para ele e "desconfortável" para o motorista, uma vez que este, para visualizar o policial, tem de rotacionar o tronco (Figura 10). Nas palavras do vistoriador:

\begin{abstract}
"Se você olhar, o motorista teve de ir até o porta-luvas para pegar os documentos, e, só depois, ele se vira e me os entrega. Esse movimento é longo e desconfortável para ele. Isso é bom [para o vistoriador]. Se um ocupante pegar uma arma no porta-luvas do carro, localizado ao lado direito, e direcioná-la para mim, o movimento vai ser muito maior. Essa posição é segura para mim, mas desconfortável para o suspeito".
\end{abstract}

Figura 10 : Posição de aproximação do vistoriador, sentido do movimento e pontos de atenção (acervo do autor, 2016)

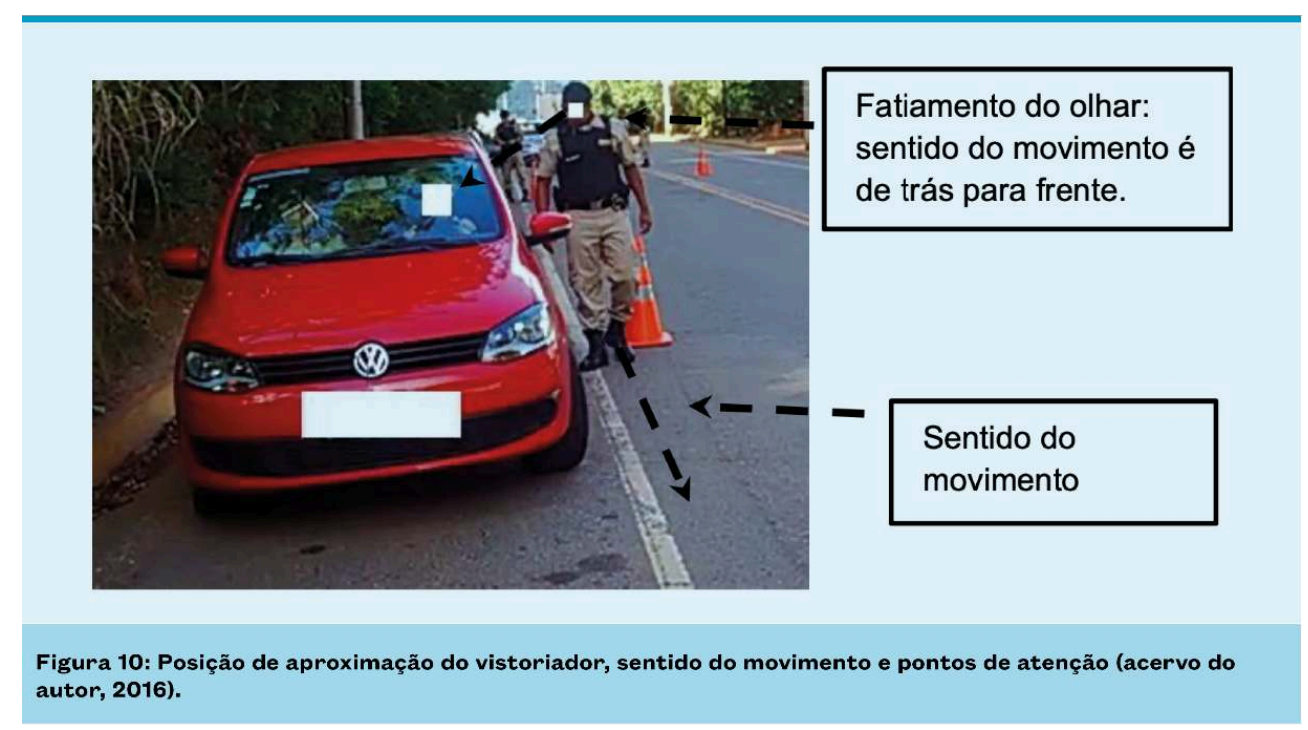

Figura 10 : Posição de aproximação do vistoriador, sentido do movimento e pontos de atenção (acervo do autor, 2016) 

respondeu:

“Ali [na posição assumida], eu estou de lado para ver a movimentação do indivíduo dentro do veículo, se tiver alguém suspeito armado e que possa estar tentando surpreender a gente. Eu estou em uma posição que me possibilita uma boa visão de dentro do veículo e do suspeito".

87

Segundo a indicação do vistoriador no vídeo, a posição mais adequada é entre as duas portas do veículo, na barra central, que é considerada pelo agente o ponto "seguro", dado que, em caso de reação, é possível abrigar-se rapidamente atrás do carro. Prosseguindo com a inquirição, o pesquisador estimula a confrontação, focalizando, primeiramente, a movimentação do indivíduo no veículo:

"Eu vi quando o condutor abriu o porta-luvas para pegar os documentos. Eu sempre fico atento a esses movimentos. Mexe na cintura, fica inquieto [o suspeito]. Há possibilidade de estar escondendo alguma arma de fogo ou volume suspeito. Quando eu venho caminhando nessa direção [da parte de trás para a parte da frente do carro], eu já vou vendo isso. Na conversa com o cara, eu fui verificando o odor, cheiro de bebida, cheiro de maconha, a forma de ele conversar, se estava com a conversa arrastada, uma voz pastosa, lenta. É instintivo. Dificuldade de o cara manusear documento...Neste caso, estava tudo OK. Não percebi nada disso".

Em seguida, o pesquisador busca saber mais a respeito da forma de conversar do suspeito:

“A pessoa geralmente não consegue simular a fala. 0 gesto, às vezes, o cara trava um pouco, mas a fala, o cara vai começar a gaguejar, não tem segurança, geralmente ele pensa um pouco para falar, ele não fala de imediato. Aquela coisa de que você desconfia, como se fosse uma aura negativa na pessoa, você, como policial, vê, e o cidadão comum não acredita. Mas é diferente. Você não sabe porque você cismou com aquele suspeito. Nesse caso em específico, não teve nada disso, conversei e não vi nada demais".

o pesquisador questiona o vistoriador sobre em que consiste o "nada de mais" por ele verbalizado:

\begin{abstract}
"Quando o cara [suspeito] está errado, o cara esboça uma reação estranha. 0 cara treme, começa a gaguejar, você pede o documento, e o cara o entrega de uma forma nervosa. Aí você começa a ver. Quando você começa a sentir isso, vai te dando um indício de estar dando mais uma verificada naquele suspeito. São coisas que você vai aprendendo".
\end{abstract}

90 A confrontação exibiu os pontos de atenção que mais se apresentaram como relevantes ao vistoriador: porta-luvas do veículo abordado; movimentos bruscos, cintura e comportamento inquieto do abordado; e volume suspeito. Segundo o agente, o diálogo com o abordado, em cujo momento ele pôde estar mais próximo do veículo, possibilitou-lhe identificar certos odores e falas que, para o policial, apresentam-se como importantes para a caracterização de suspeição. Assim, foi-lhe indagado sobre a forma de conversar do condutor, incluindo-se o conteúdo da conversa e quais as 
respostas dadas pelo abordado que se mostraram fundamentais para a percepção do vistoriador. Ele responde:

“Cheguei e [cumprimentando] “boa tarde!' e solicitei documentação. [Perguntei-lhe] para onde ele estava indo e de onde vinha. Ele estava vindo da cidade " $x$ ' sentido BH. São coisas que a gente vai perguntando para ver se confronta alguma informação, para ver se ele fica nervoso. Depois, eu verifiquei a documentação, está vendo [apontando na direção do vídeo]? Pego os documentos e vou atrás do carro e verifico se os dados estão batendo com o documento. Não vi nada [estranho], estava tudo certo".

91 Percebe-se, pela confrontação, que a fala é usada a todo momento pelo vistoriador, em um movimento constante de confrontação entre as percepções e as sensações que o policial tem acerca do abordado. Ela possibilita ao agente diminuir as desconfianças ou reforçar a suspeição em relação ao abordado. A estratégia do diálogo com o outro garante ao policial um momento de interação, que facilita a percepção e detecção de comportamentos suspeitos, das quais decorrem o aumento ou a diminuição da suspeita em relação ao abordado, melhora a precisão de suas análises e torna a abordagem mais fácil de ser conduzida. 0 resultado da interação do policial com o abordado é o ajuste da intuição daquele em relação a este, o que culminará em uma ação mais eficaz.

Em dado momento da conversa, o vistoriador coloca a mão no rádio. Quando questionado sobre o porquê daquele movimento e qual a sua intenção com ele, o agente responde:

\footnotetext{
"Eu, naquele momento, usava o rádio na canaleta principal para ouvir as ocorrências gerais, pois pode haver roubos nas imediações, e eu tenho de estar atento ao que está acontecendo. Dependendo da operação, nós podemos ter uma canaleta alternativa entre nós, para eu conversar com o comandante ou o motoqueiro, para poder estar me comunicando com eles. Às vezes, passa um carro aqui que eles não iam parar, mas, como eu observei um volume dentro do carro que passou perto de mim devagarinho, que passou por mim e não dá mais para eu parar, eu comunico com o comando: “ô sargento, para esse carro aí!".
}

Pode-se perceber, na fala do vistoriador, que a atividade de seleção não é exclusiva ao balizador; ele também fica atento aos carros que se aproximam da operação. Isso não condiz com a perspectiva do balizador, que acreditava que a visão do seu colega se dedicava exclusivamente aos condutores dos veículos. Assim, a atividade de seleção e identificação apresenta-se como uma atividade coletiva, em especial, realizada por balizador e vistoriador. Essa diferença interpretativa se dá pelo equívoco do balizador em supor que consegue cobrir toda a segurança da operação. $O$ vistoriador deixa claro que, apesar de estar "coberto" pelo balizador, ele sempre olha ao redor e dentro dos carros que passam na operação.

Além disso, o rádio foi usado como ferramenta de auxílio à operação. Para o vistoriador, ele serve para incluir ou excluir características que devam chamar sua atenção e, por meio dele, crimes que ocorrem na região são informados aos agentes em operação: "nessa operação, eu estava usando o rádio na canaleta principal, porque, quando tem crimes na região, 'sai' nela [é informada por ela] primeiro. [0 rádio] permite que o agente fique sabendo de crimes nas proximidades da operação".

95 Assim, emerge a hipótese, proposta por este trabalho, sobre o processo de tomada de decisão a respeito da seleção de um abordado. A verificação eficaz de tal indivíduo é 
uma ação situada e contextualizada, resultado do acoplamento adequado das experiências do agente com a situação encontrada. Determinadas regiões - como cintura, pernas, mãos, porta-luvas, bancos traseiros e assoalhos - e comportamentos como nervosismo, gagueira, olhar desviante, fala pastosa, excessiva ou escassa e muita solicitude - são atratores para ação em situação. O ponto-chave da habilidade de verificação são as experiências acumuladas, configurando uma realidade percebida. De acordo com o sargento balizador:

"O que faz a gente escolher são as atitudes. Na maioria das vezes, são as atitudes das pessoas, de ver a operação e tomar aquele baque. Esse tipo de atitude é o que me faz escolher [o abordado]. Dá para desconfiar das atitudes do cara que está vindo atrás do carro. Ele vê a operação, eu sei que ele viu. Então, ele deu aquela titubeada, jogando a moto mais para o lado de lá, escondendo-se da minha posição. Ele me vê e joga a moto para lá. Esse cara, eu já mando diminuir o carro para fazê-lo passar (...) Eu vou me basear nisso. Olha: carro com grandes quantidades de pessoas, muitos homens dentro, indicamos para parar. Se tem arma, se tem droga, de onde está vindo, para onde vai. (...) E isso [essa percepção], só com o tempo. Tirocínio é como se fosse uma intuição. (...) Eu já vi a vestimenta, a postura, mãos trêmulas, fala pastosa. Praticamente impossível de estar armado. Você já olha e já identifica. No caso, não passou de nervosismo, aí o liberei".

O policial usa a estratégia de detecção de aspectos de suspeição, ajustando-a a cada situação, incluindo e excluindo "abertos" de possibilidades, associados às percepções e ações que aquela situação requer. Logo, toda a habilidade em detecção é relativa; depende do contexto e do abordado.

Se a competência depende primordialmente da situação e da prática, a habilidade do corpo entrelaçada às regras, e a "intuição" mencionada pelo agente não é adquirida por meio de representações, é somente em situação e pela prática que a seleção e ação policial podem resultar em abordagem eficaz e proporcional. Isso não implica que não ocorram erros ou excessos.

Não há indícios nos resultados que indiquem que não há preconceitos nas deliberações e processos perceptivos participando nas atividades. Desde discursos extremamente carreados de carga moral ("homens de bem", "maldade", entre outros) até a descrição de exemplos que seriam suspeitos, são exemplos de como as "tomadas de decisão" incluem conhecimento acumulado que não se dá, aparentemente, totalmente ancorado na realidade prévia. Além disso, se se entender o preconceito como uma orientação prévia às ações, ancoradas em juízos sociais de diferenciação de grupos sociais, é difícil imaginar que a cultura policial não inclui tais dimensões.

o que os resultados mostram é que esse preconceito, se ele existe, é ancorado em situações concretas, numa espécie de coprodução complexa que não pode indicar que ser policial é ser preconceituoso, pois situações reais balizam, produzem, transformam tais preconceitos.

\section{Considerações finais}

Buscar entender com mais detalhes o processo de tomada de decisão no contexto de atuação policial é de grande relevância por uma série de motivos, já citados. 
101 Quase sempre, quando se fala em "abordagem policial", a expressão vem carregada de preconceitos e implicações negativas, que conotam tratamento cruel e brutalidade, o que, de certo modo, corrói a confiança social em relação às instituições policiais. Assim, além dos efeitos negativos criados nas relações entre a comunidade e os agentes, podem ser gerados conflitos judiciais.

O trabalho empírico teve como objetivo compreender o processo de tomada de decisão e traduzir, em parte, as ações adotadas por policiais militares em situações de abordagem, por meio de articulação autoconfrontação entre os saberes - experiências e habilidades - e os aspectos inerentes ao contexto situado. Os policiais são agentes conhecedores da prática de policiamento e da identificação de suspeitos, já que são profissionais experientes. Assim, as descobertas aqui trazidas são baseadas em interpretações válidas de eventos no mundo real.

Os agentes relataram e manifestaram diversas formas de julgamento perceptivos, como palpite, sensação e intuição. O papel desempenhado pela percepção no processo de tomada de decisão foi evidenciado como um fator importante para a eficácia das respostas dos policiais aos cidadãos abordados, dado que a habilidade de detecção de indícios de suspeição se baseia nas condições do contexto e nos comportamentos. Vale ressaltar, contudo, que o preconceito é uma interpretação socialmente partilhada de aspectos observados de contextos e/ou características de grupos sociais. Daí não serem aspectos totalmente divergentes. Assim, procurou-se entender se os policiais participantes eram sensíveis à detecção de indícios de suspeição, ou seja, se o processo decisório de resposta à intuição policial era justificado ou injustificado, chegando-se a um resultado afirmativo.

Os seguintes fatores - cujos resultados se recomenda aplicar na prática - mostraram ser de grande importância para o bom andamento da abordagem:

i. Trabalhar com a mesma equipe por muito tempo eleva o grau de entrosamento e coletividade dos policiais, o que, por sua vez, aumenta a rapidez das comunicações entre eles e das respostas às ameaças. Aconselha-se manter os mesmos policiais na mesma equipe sempre que possível. Deve-se criar uma escala de revezamento, compreendendo férias, atestados, aposentadorias etc., que diminua ao máximo a influência da troca de policiais em uma equipe. Pesquisas futuras poderão auxiliar a resolver esse problema, propondo a melhor maneira de realizar tais revezamentos.

ii. Recomenda-se a criação de um grupo de retorno de experiências (REX) em abordagens, cuja finalidade seja a criação de um ambiente de discussão, em que se compartilhariam experiências. A câmera de vídeo como aparato tecnológico em carros e coletes já é uma realidade em alguns países. Com este recurso, os agentes brasileiros poderiam, com as imagens, discutir e analisar erros e acertos, e os policiais experientes, explicar o engajamento de suas decisões.

105 Diante de tais fatores, este artigo trouxe avanços no conhecimento atual a respeito de abordagens policiais. Ela não tratou apenas sobre em que consiste o processo de tomada de decisão, mas sobre como este se faz presente nas abordagens policiais, dado que possibilitou entender, empiricamente, como a percepção é usada a partir das experiências dos policiais, em vez de se pautar somente por análises teóricas e controladas; como os estudos de Blair et al. (2010), Zimmerman (2008), e Endsley (1995) apresentam.

A presente pesquisa forneceu evidências que traduzem, em parte, a atividade policial, apresentando uma explicação possível para o funcionamento dos processos e 
subprocessos da seleção de um abordado e expandindo o entendimento sobre o fenômeno abordagem. A investigação também analisou os "atalhos" que realmente aparecem na prática policial.

Embora este trabalho ofereça um argumento mais plausível e diferenciado para o debate sobre o processo de abordagem policial, ela não é livre de limitações. Os resultados aqui descritos carecem de ser conferidos e analisados em relação a pesquisas que se valem de outros procedimentos. Também é possível superar as limitações aqui encontradas refazendo as análises com o uso de novas tecnologias, como câmeras instaladas em cada policial e óculos com identificação da direção do olhar, possibilitando confrontações mais refinadas.

Pesquisas futuras poderão extrapolar as restrições inerentes a esta pesquisa estudando outros domínios policiais. Elas poderão, por exemplo, entender o papel do negociador na leitura e interpretação do sequestrador; analisar o papel do investigador na deteç̧ão de mentiras em interrogatórios; estudar as operações de entrada em comunidades; analisar os "erros" policiais; verificar se a detecção de mentira pode ser automatizada; e avaliar se policiais experientes são mais sensíveis na detecção de traços suspeitos que os menos experientes.

109 Finalmente, as políticas de segurança pública, devem ser mais baseadas em pesquisas empíricas, bem como é necessário que se compreendam completamente a natureza e a extensão das abordagens policiais e os fatores relacionados a sua seleção.

\section{BIBLIOGRAFIA}

Ask, K., \& Granhag, P. A. (2003). Individual Determinants of Deception Detection Performance: Need for Closure, Attributional Complexity and Absorption. Complexity, 1(33), 1-13.

Belli, B. (2016). Direitos humanos, violência policial e espaço público: uma reflexão a partir do pensamento de Hannah Arendt. Revista do Instituto Brasileiro de Direitos Humanos, 2, 43-51.

Blair, J., Levine, T., \& Shaw, A. (2010). Content in Context Improves Deception Detection Accuracy. Human Communication Research, 36(3), 423-442. https://doi.org/10.1111/j. 1468-2958.2010.01382.x

Brasil, CTN. Lei nº 5.172, de 25 de Outubro de 1966 (2010). Dispõe sobre o Sistema Tributário Nacional e institui normas gerais de direito tributário aplicáveis a União, Estados e Municípios.

Castillo, P., \& Mallard, D. (2012). Preventing Cross-Cultural Bias in Deception Judgments: The Role of Expectancies About Nonverbal Behavior. Journal of Cross-Cultural Psychology, 43(6), 967-978. https://doi.org/10.1177/0022022111415672

CEPM (2021). Polícias Civil e Militar: quais são as diferenças entre as duas? Disponível em: https:// www.cepmpremilitar.com.br/

De Paula, C. (2007). Intuição, linguagem não-verbal e o compartilhamento da experiência vivida: um estudo sobre o processo de vendas de aeronaves executivas (Dissertação de mestrado). Universidade Federal de Minas Gerais, Brasil. 
Endsley, M. (1995). Toward a theory of situation awareness in dynamic systems. Human Factors, 37, 32-64. https://doi.org/10.1518/001872095779049543

FBSP - Fórum Brasileiro de Segurança Pública (2015). Anuário brasileiro de segurança pública 2015. São Paulo: FBSP. Disponível em https://forumseguranca.org.br/storage/

9_anuario_2015.retificado.pdf

FBSP - Fórum Brasileiro de Segurança Pública (2016). Anuário brasileiro de segurança pública 2016. São Paulo: FBSP. Disponível em https://www.forumseguranca.org.br/storage/

10_anuario_site_18-11-2016-retificado.pdf

Gladwell, M. (2016). Blink: a decisão num piscar de olhos. Sextante.

Guérin F., Laville, A., Daniellou F., Duraffourg J., \& Kerguelen A. (2001). Compreender o trabalho para transformá-lo: a prática da ergonomia. São Paulo: Edgar Blücher.

Guimarães, J., Torres, A., \& De Faria, M. (2005). Democracia e violência policial: o caso da polícia militar. Psicologia em estudo, 10(2), 263-271.

Harris, K., Tashman, L., Ward, P., Ericsson, K., \& Eccles, D. (2006). Planning, evaluation, and cognition: Exploring the structure and mechanisms of expert performance in a representative dynamic task. Proceedings of the Annual Meeting of the Cognitive Science Society, 28, 327-332.

Holloway, T. H., \& de Castro Azevedo, F. (1997). Polícia no Rio de Janeiro: repressão e resistência numa cidade do século XIX. Rio de Janeiro: Fundação Getúlio Vargas.

HRW - Human Right Watch (2021, 11 de Janeiro). Relatório mundial 2016: Brasil. Disponível em https://www.hrw.org/pt/world-report/2016/country-chapters/285573

Klahm, C., \& Tillyer, R. (2010). Understanding police use of force: A review of the evidence. Southwest journal of criminal justice, 7(2), 214-239.

Klinger, D. (2004). Into the kill zone: A cop's eye view of deadly force. San Francisco: Jossey-Bass.

Marconi, M., \& Lakatos, E. (2003). Fundamentos de metodologia científica (5⿳a edição). São Paulo: Editora Atlas.

Pinheiro, P. (1997). Violência, crime e sistemas policiais em países de novas democracias. Tempo social, $9(1), 43-52$.

Portela, A., \& Bughay Filho, A. (2007). Nível de estresse de policiais militares: comparativo entre sedentários e praticantes de atividade física. Lecturas: Educación física y deportes, 106. Disponível em https://www.efdeportes.com/efd106/nivel-de-estresse-de-policiais-militares.htm

Reiner, R. (2004). A política da polícia. São Paulo: USP.

Reis, G. (2016). “Nem cora o livro de ombrear co'o sabre, nem cora o sabre de chamá-lo irmão": a dualidade de "habitus" da cultura policial-militar. 2016 (Tese de Doutorado). Pontifícia Universidade Católica de Minas Gerais (PCU-MG), Belo Horizonte, Brasil.

Ribeiro, A. (2013). A influência da personalidade na detecção da mentira (Dissertação de mestrado). Instituto Superior de Ciências da Saúde Egas Moniz, Portugal.

Sadler-Smith, E., \& Akinci, C. (2014). Enacting intuitions as skillful performance: the case of police officers' first-response decisions. Academy of Management Proceedings, 1, 14192. https://doi.org/ 10.5465/ambpp.2014.14192abstract

Silva, S. (2004). Gestão do conhecimento: uma revisão crítica orientada pela abordagem da criação do conhecimento. Ciência da Informação, 33(2), 143-151. https://doi.org/10.1590/ S0100-19652004000200015 
Suss, J., \& Ward, P. (2013). Investigating Perceptual Anticipation in a Naturalistic Task using a Temporal Occlusion Paradigm A Method for Determining Optimal Occlusion Points. Proceedings of the Human Factors and Ergonomics Society Annual Meeting, 57(1). 304-308. https://doi.org/ $10.1177 / 1541931213571067$

Theureau, J. (2014). o curso da ação. Método Elementar. Belo Horizonte: Fabrefactum.

Vrij, A. (2000). Detecting Lies and Deceit: The Psychology of Lying and Implications for Professional Practice. Portsmouth: Wiley.

Zimmerman, L. (2008). Making sense of human behavior: Explaining how police officers assess danger during traffic stops. In J. Schraagen, L. Militello, T. Ormerod, \& R. Lipshitz (Eds.), Naturalistic decision making and macrocognition (pp. 121-140). Aldershot: Ashgate Publishing.

\section{RESUMOS}

O presente artigo tem por objetivo analisar a complexidade da tomada de decisão e do julgamento de policiais militares do 26ํㅡ Batalhão de Polícia de Minas Gerais, fazendo uso do seu poder discricionário de polícia em ação de abordagem policial. Desta forma, o objetivo geral será de evidenciar as variáveis e os fatores associados a esse "poder", por meio de observações e autoconfrontações em campo, fazendo uso da Análise ergonômica do Trabalho. Todo o texto trará análises sobre a seguinte problemática: como são tomadas as decisões em uma abordagem policial? o que se percebeu é que grande parte das decisões e julgamentos tomados são baseados em habilidades resultantes do acoplamento adequado das experiências do agente com a situação encontrada. O ponto-chave da habilidade são as experiências e vivências acumuladas em situações diversas. Logo, toda a habilidade em detecção é relativa; depende do contexto e do suspeito.

El propósito de este artículo es analizar la complejidad de la toma de decisiones y el juicio de los policías militares del 26. Batallón de Policía de Minas Gerais, haciendo uso de su poder policial discrecional en una acción de abordaje policial. De esta forma, el objetivo general será resaltar las variables y los factores asociados a este "poder", a través de observaciones y autoconfrontaciones en el campo, recurriendo al Análisis Ergonómico del Trabajo. Todo el texto analizará el siguiente problema: ¿cómo se toman las decisiones en un enfoque policial? De lo que se ha constatado es que una gran parte de las decisiones y juicios que se toman se basan en habilidades resultantes del adecuado acoplamiento de las experiencias del agente con la situación encontrada. El punto clave de la habilidad son las experiencias acumuladas en diferentes situaciones. Por lo tanto, todas las habilidades de detección son relativas; dependen del contexto y del sospechoso.

Le but de cet article est d'analyser la complexité de la prise de décision et du jugement des policiers militaires du 26e bataillon de police de Minas Gerais, en recourant à leur pouvoir discrétionnaire de policier dans l'action de l'approche policière. L'objectif général est ainsi de mettre en évidence les variables et les facteurs associés à ce "pouvoir», grâce à des observations et des auto-confrontations menées sur le terrain, en ayant recouru à l'Analyse Ergonomique du Travail. L'ensemble du texte analyse le problème suivant: comment les décisions sont-elles prises dans une approche policière? Le constat est qu'une grande partie des décisions et des jugements portés repose sur des habiletés résultant d'un couplage approprié des expériences de l'agent avec la situation rencontrée. Le point clé de l'habileté provient d'expériences accumulées en différentes situations. Par conséquent, toute habileté de détection est relative; elle dépend du contexte et du suspect. 
The purpose of this article is to analyze the complexity of decision-making and the judgment of military policemen of the $26^{\text {th }}$ Minas Gerais Police Battalion, using their discretionary police power during the action of a police approach. In this way, the general objective will be to highlight the variables and factors associated with this "power", through observations and selfconfrontations in the field, making use of the Ergonomic Analysis of Work. The whole text will analyze the following problem: how are decisions made in a police approach? What has been realized is that a large part of the decisions and judgments are based on skills resulting from the appropriate coupling of the agent's experiences with the situation found. The key point of the skill are the experiences accumulated in different situations. Therefore, all detection skills are relative; it depends on the context and on the suspect.

\title{
ÍNDICE
}

Palabras claves: toma de decisiones, juicio, percepción

Keywords: decision making, judgment, perception

Palavras-chave: tomada de decisão, julgamento, percepção

Mots-clés: prise de décision, jugement, perception

\author{
AUTOR \\ GUILHERME FERNANDO SOARES DE ARAÚJO \\ https://orcid.org/0000-0002-5365-4476 \\ Universidade Federal de Uberlândia na Escola Técnica de Saúde - ESTES, Avenida central, 1185, \\ Jardim Ipanema, Uberlândia/MG, CEP 38.406-202 \\ guilhermearaujo.unifei@gmail.com
}

